\title{
A CULTURAL PLURALIST CASE FOR AFFIRMATIVE ACTION IN LEGAL ACADEMIA
}

\author{
DUNCAN KENNEDY*
}

This Article is about affirmative action in legal academia. It argues for a large expansion of our current commitment to cultural diversity on the ground that law schools are political institutions. For that reason, they should abide by the general democratic principle that people should be represented in institutions that have power over their hives. Further, large scale affirmative action would improve the quality and increase the value of legal scholarship.

My goal is to develop in the specific context of law school affirmative action the conception of "race consciousness" that Gary Peller describes and advocates in his essay in this issue of the Duke Law Journal. " We need to be able to talk about the political and cultural relations of the various groups that compose our society without falling into racialism, essentialism, or a concept of the "nation" tied to the idea of sovereignty. We need to conceptualize groups in a "post-modern" way, ${ }^{2}$ recognizing their reality in our hives without losing sight of the partial, unstable, contradictory character of group existence.

I present my argument in the forn of a dialogne with our society's dominant way of understanding race and merit in academia, which I call "colorblind meritocratic fundamentalism." I use Randall Kennedy's ar-

Copyright (C) Duncan Kennedy 1990.

- Professor of Law, Harvard Law School. I would like to thank Fran Ansley, Kyra Armstrong, Regina Austin, Ed Baker, Robin Barnes, Derek Bell, Marjorie Benson, Jamie Boyle, Kim Crenshaw, Richard Delgado, Karen Engle, Neil Gotanda, Randy Kennedy, Larry Kolodney, Martha Minow, Gary Peller, Merle Weiner, and David Wilkins. Special thanks to Peter Gabel.

1. Peller, Race Consciousness, 1990 Duke L.J. 758. Two other articles that strongly influenced this one are Freeman, Legitimizing Racial Discrimination Through Anti-Discrimination Law, 62 MiNv. L. REv. 1049 (1978) [hereinafter Freeman, Legitimizing Racial Discrimination], and Freeman, Racism, Rights and the Quest for Equality of Opportunity: a Critical Legal Essay, 23 HARv. C.R.-C.L. L. REV. 295 (1988) [hereinafter Freeman, Racism].

2. See (very) generally J.-F. LyotaRd, THE POSTMOdern CONDITION: A Report ON KNolvledge (G. Bennington \& B. Massunn trans. 1984); J. Gallop, Thinking Through the BODY (1988). The writer who has unost influenced my thinking about race is Harold Cruse. See $\mathrm{H}$. Cruse, The Crisis of the Negro Intellectual (1967); H. Cruse, Rebellion or RevoluTION? (1968). 
ticle, Racial Critiques of Legal Academia ${ }^{3}$ as principal representative of this point of view. Throughout, I will be responding to Kennedy's general understanding of how we should organize legal academic life in a situation of racial and cultural division, rather than to his specific attacks on works of race-conscious scholarship.

I think the articles Kennedy discusses ${ }^{4}$ and the others in the genre of Critical Race Theory, ${ }^{5}$ represent the most exciting recent development in American legal scholarship. On some issues, I agree with Kennedy's criticisins. ${ }^{6}$ But overall I see the articles as developing positions that I share, and I don't find his article convincing as a refutation of thein. ${ }^{7}$ I

3. R. Kennedy, Racial Critiques of Legal Academia, 102 HARv. L. Rev. 1745 (1989). For other responses to Randall Kennedy's article, see Colloquy: Responses to Randall Kennedy's Racial Critiques of Legal Academia, 103 HARV. L. REv. 1844 (1990) (responses by Brewer, Ball, Barnes, Delgado, and Espinoza); Delgado, When a Story is Just a Story: Does Voice Really Matter?, 76 VA. L. REV. 95 (1990).

4. Bell, Bakke, Minority Admissions, and the Usual Price of Racial Remedies, 67 CALIF. L. REv. 1 (1979) [hereinafter Bell, Minority Admissions]; D. BELL, The Unspoken Limit of Affirmative Action: The Chronicle of the DeVine Gift, in AND WE ARE NOT SAVED: THE ELUSIVE QUEST FOR RACiAl JUstice 140 (1987) [hereinafter D. DeLL, AND We ARE Not SAVEd]; Delgado, The Imperial Scholar: Reflections on a Review of Civil Rights Literature, 132 U. PA. L. REV. 561 (1984) Matsuda, Affirmative Action and Legal Knowledge: Planting Seeds in Plowed-Up Ground, 11 HARv. WOMEN's L.J. 1 (1988) [hereinafter Matsuda, Affirmative Action]; Matsuda, Looking to the Bottom: Critical Legal Studies and Reparations, 22 HARV. C.R.-C.L. L. REV. 323 (1987) [hereinafter Matsuda, Looking to the Bottom].

5. Critical Race Theory is an "emergent" phenomenon, and it may turn out that these articles do not have as much in common as they appear to me to do. This hist is illustrative only. I am not familiar with the entire hiterature. This list is not an attempt to establish a canon. Austin, Sapphire Boundl, 1989 Wis. L. REv. 539; Calmore, Exploring the Signiffcance of Race and Class in Representing the Black Poor, 61 OR. L. REv. 201 (1982); Cook, Beyond Critical Legal Studies: The Reconstructive Theology of Dr. Martin Luther King, Jr., 103 HARV. L. Rev. 985 (1990); Crenshaw, Race, Reform and Retrenchment: Transformation and Legitimation in Antidiscrimination Law, 101 Harv. L. Rev. 1331 (1988); Kenyatta, Critical Footnotes to Parker's "Constitutional Theory," HARV. Blackletter J., Spring 1985, at 49; Lâm, The Kuleana Act Revisited: The Survival of Traditional Hawaiian Commoner Rights in Land, 64 WASH. L. REV. 233 (1989); Lawrence, The Id, the Ego, and Equal Protection: Reckoning with Unconscious Racism, 39 STAN. L. REv. 317, 324 (1987); Lopez, Training Future Lawyers to Work with the Politically and Socially Subordinated: Anti-Generic Legal Education, 91 W. VA. L. REv. 305 (1989); McDougall, The New Property us. the New Community, 24 U.S.F. L. REv. 399 (1990); Torres, Local Knowledge, Local Color: Critical Legal Studies and the Law of Race Relations, 25 SAN DIEGo L. REv. 1043 (1988); Willinms, Alchemical Notes: Reconstructing Ideals from Deconstructed Rights, 22 HARV. C.R.-C.L. L. REV. 401 (1987). See generally Ansley, Stirring the Ashes: Race, Class and the Future of Civil Rights Scholarship, 74 CORNELl L. REv. 993 (1989).

6. Like Randall Kennedy, I see it as a weakness of current attempts at radical politics in the United States that we tend to sentimentalize all "victims of oppression." Another weakness is a tendency to exaggerate the relative importance of eurrent racism in explaining racially unjust outcomes, and, by contrast, to underestimate the relative inportance of past racism, and non-race econonic and institutional factors.

7. With Derrick Bell, I regard race, a proxy for connection to a subordinated cultural coinmumity, as an intellectual credential in hiring and promotion decisions. See infra Part II. A. I agree with Mari Matsuda, as paraphrased by Kennedy, that "by the exclusions imposed by existing prac- 
think it's best to leave it to the authors to debate him point by point. I am inore interested in working out a left wing (white ruling class male academic) take on the underlying questions than I am in discussing whether his article is "fair."

Part I presents colorblind meritocratic fundamentalisin, a systein of ideas about race, merit and the proper organization of academic institutions. Fundamentalisin is a critique of race-conscious decisionmaking in academia. Part II presents what I call the pohtical and cultural cases for large-scale affirmative action. The political case is based on the idea that the intelligentsias of subordinated cultural communities should have access to the resources that are necessary for groups to exercise effective political power. The cultural case is based on the idea that a large increase in the nuniber of minority legal scholars would improve the quality and increase the social value of legal scholarship, without being unfair to those displaced.

Part III presents a "cultural pluralist" understanding of American life, one which recognizes that there are dominant and subordinate coininunities coinpeting in inarkets and bureaucracies. It proposes that the political and cultural good effect to be anticipated from affirmative action is the development within legal scholarship of the ideological debates that minority intelligentsias have pursued in other fields. Part IV takes up the question whether race-conscious legal academic decisionmaking "derogates froin the individuality" of minority scholars. It concludes that we can judge scholarship without regard to culture and ideology ouly if we are willing to use criteria of judgment that leave out the inost important aspects of legal academic accomplishment. Part $\mathrm{V}$ is a brief conclusion.

\section{COLORBLIND MERITOCRATIC FundAMENTALISM}

My attitude toward ineritocracy grows froin my experience as a white inale ruling class child who got good grades, gained admission to one elite institution after another, and then landed a job and eventually tenure at Harvard Law School. I belong to a group (only partly generationally defined) that since soine point in childhood has felt alienated within this hived experience of working for success according to the criteria of merit that these elite institutions administer.

tices, legal academia loses the sensibilities, insights, and ideas that are the products of racial oppression." R. Kennedy, supra note 3, at 1778. See infra Part III. B. And I agree with Richard Delgado that we are entitled to judge with suspicion the work produced in a field like constitutional law on the basis of the "status," i.e., the cultural community, of the authors. See infra Part IV. C. 
This alienation had and has two facets. First is a pervasive scepticism about the "standards" according to which we have achieved success. Always subject to the charge that we are simultaneously biting the hand that feeds us and soiling the nest, we just don't believe that it is real "merit" that institutions measure, anywhere in the system; success is a function of particular knacks, some socially desirable (being "smart") and some not (sucking up)-and of nothing more grandiose. This is not rejection of the idea that some work is better than other work. It is rejection of the institutional mechanisms that currently produce such judgments, of the individuals who manage the institutions, and of the substantive outcomes.

The second facet is a sense of shanie and guilt at hiving in unjust, segregated racial privilege, combined with a sense of loss from the way we have been diminished by isolation from what the subordinated cultural communities of the U.S. might have contributed to our hives, intellectual, pohtical and personal. I might add that the members of this wholly hypothetical group have not done anuch (but not nothing, either) about the situation.

These attitudes were held by a scattering of people within elite institutions, and we had hittle contact with people outside that milieu. The experience on which the reaction was and is based is limited. It's hard to know whether the attitudes are really right. It's hard to know whether there is any alternative to the actual system that would work.

During the 1960s, these attitudes fed into the much larger complex of the New Left, the Movement and the Women's Movement. The participants canie from many different sectors of society. They were male and female, white and black, upper middle, middle, and-to a himited extent-working class. The whole thing was over before the deep differences aniong them were worked into anything like coherence. It remains an open question just how the anti-1neritocratic alienation $I$ have described dovetails or doesn't with the attitudes of people who come from disadvantaged or non-ehte backgrounds.

When pohitical alliancc and real communication between black and white and male and female radicals fell apart in the 1970s, the project of working out a critique of meritocracy sphit apart too. But before that happened, there was a counterattack, associated with the general reaction against 1960s militancy and specifically addressed to the various contradictory radical critiques that had gained some currency. This reaction, which I call fundamentalism, won the day. It became one of the ideological legitimaters of society's retreat from messing around with established institutions. 
Colorblind meritocratic fundamentalism is a set of ideas about race and merit. Like other substructures within the consciousness of a time, it is no more than one of many fragments out of which people construct their personal philosophies. It is intrinsically neither right nor left, male nor female, black nor white. Fundamentalism has a long history within American liberalism, and within orthodox Marxisin, as well as within the conservative tradition.

\section{A. Fundamentalism as a System of Ideas}

Fundamentalism consists of a set of tenets. ${ }^{8}$ Each is a slogan with appeal of its own. They are rarely presented all together. Believers deploy thein one by one as the argument may require. Some tenets are about knowledge and others about the social value of individuals and their work.

1(a.) Knowledge:

i. Attributes of the product rather than of the producer determine the value of purported contributions to knowledge.

in. In judging the value of a product, the race, sex, class, and indeed all the other personal attributes of the producer are irrelevant (derived from (i)).

Kennedy identifies these tenets with "tlie ethos of moderu science."9 The scientific ideal is linked to an image of how intellectual work is done.

1(b.) The production of knowledge:

i. We produce work by individual application of talent to inert matter.

ï. The value of the work is a function of the quality of the individual talent that produced it rather than of the inert Inatter of experience out of which the individual formed it (derived froin (i)).

Fundamentalism includes the complex of liberal attitudes toward race that Peller calls integrationism, ${ }^{10}$ but which seems to me better called colorblindness. ${ }^{11}$ Kennedy's article displays better than any recent document I know of the way meritocracy and colorblindness can be made mutually supportive. 12

For our purposes liere, the important tenets of colorblindness are as follows:

8. This Section is indebted to Peller, supra note 1 and to Freeman, Racism, supra note 1.

9. R. Kennedy, supra note 3, at 1772-73.

10. Peller, supra note 1 , at 767-71.

11. See N. Gotanda, A Critique of "Our Constitution is Colorblind": Racial Categories and White Supremacy (1990) (unpublished manuscript) (available from the author).

12. I do not mean to reify either. One might be a meritocrat and also a nationalist, in Peller's terminology, or a person indifferent to the racial consequences of meritocratic processes. Likewise, one might favor colorblindness and still beheve wholeheartedly in the critique of meritocracy. 
2(a.) "Prejudice" and "discrimination" are defined in opposition to "assessment of individuals on their merits":

i. Merit is a matter of individual traits or products.

ii. People are treated irrationally and unjustly, in short they are discriminated against, when their merit is assessed according to their status rather than according to the value of their traits or products (derived froin (i)).

2(b.) Racial discrimination as stereotyping:

i. There is no reason to beheve that race in any of its various socially constructed ineanings is an attribute biologically linked to any particular meritorious or discreditable intellectual, psychological or social traits of any kind.

ii. Racial discrimination is irrational and unjust because it demes the individual what is due him or her under the society's agreed standards of merit (derived froin (i)).

From these two sets of tenets, the fundamentalist moves easily to propositions about the proper imstitutional organization of academic (and other) rewards and opportunities.

3. The institutional organization of the production of knowledge:

i. Academic institutions should strive to inaximize the production of valuable knowledge and also to reward and einpower individual inerit.

ii. Institutions distributing honor and opportunity should therefore do so according to criteria blind to race, sex, class, and all other particularities of the individual except the one particularity of having produced work of value (derived from (i) plus 1 and 2).

\section{B. Colorblind Meritocracy and Affirmative Action}

Fundamentalism does not preclude adopting affirmative action programs so long as we recognize that they conflict with meritocratic allocation, and that the sacrifice of meritocratic to race-based outcomes is a social cost or loss. But, in this view, versions of affirmative action that obscure the cost by distorting standards in favor of minorities end up compounding it. They go beyond departure from merit in particular cases to endanger the integrity of the general system of unbiased judgment of value.

The political and cultural arguments for affirmative action I put forward in the next section are consistent with fundamentalism in that they openly abandon the use of colorblind criteria, rather than distorting thein in order to achieve desirable results. They do not treat race as an index of merit in the sense of making it a source of honor in and of itself, nor 
presume that minority scholars are, just by virtue of their skin color, "better" scholars. ${ }^{13}$

There remains an important area of disagreement. Fundamentalism treats a colorblind meritocratic system as the ideal. Kennedy's article, for example, concedes (even affirms) that our actual system departs very far from the ideal, ${ }^{14}$ but urges that we should therefore redouble our commitment to purifying it:

It is true ... that there are many nonracial and ameritocratic considerations that frequently enter into evaluations of a scholar's work. The proper response to that reality, however, is not to scrap the meritocratic ideal. The proper response is to abjure all practices that exploit the trappings of meritocracy to advance interests ... that have nothing to do with the intellectual characteristics of the subject being judged. ${ }^{15}$

If the concern is with racial justice, then loyalty to meritocracy suggests two paths. First, according to Kennedy, "there is nothing necessarily wrong with race-conscious affirmative action"16 if one has a good reason for it, but the reasons he imagines include neither cultural diversity as an intellectual desideratum nor the recognition of the cultural and ideological relativity of the standards that faculty members apply im distributimg jobs and honors.

[O]ne might fear that without a sufficient number of minority professors a school will be beset by an intolerable degree of discord or beheve that an institution ought to make amends for its past wrongs or insist upon taking extraordinary measures in order to integrate all socially significant institutions in American life. ${ }^{17}$

Second, Kennedy favors attacking the underlying social conditions, particularly the class stratification, that reduce the pool of minority applicants. ${ }^{18}$

The point about affirmative action seen as peace making, reparations or integration for its own sake, and also about increasing the pool of minority apphicants, is that all of them allow us to preserve a sharp boundary between meritocratic decision and race-based decision:

I simply do not want race-conscious decisionmaking to be naturalized into our general pattern of academic evaluation. I do not want raceconscious decisionmaking to lose its status as a deviant mode of judg-

\footnotetext{
13. None of the authors Kennedy criticizes take this position either.

14. R. Kennedy, supra note 3, at 1806.

15. Id. at 1807.

16. $I d$.

17. $I d$.

18. Id. at $1768,1770,1814$ n.296.
} 
ing people or the work they produce. I do not want race-conscious decisionmaking to be assimilated into our conception of meritocracy. ${ }^{19}$ The political and cultural cases for affirmative action propose to do each of these things.

\section{The Political and Cultural Arguments FOR AfFirmative Action}

\section{A. The Political Case}

I favor large scale race-based affirmative action, using quotas if they are necessary to produce results. The first basis for this view is that law school teaching positions are a sinall but significant part of the wealth of the United States. They are also a small but significant part of the political apparatus of the Uinted States, by which I mean that the knowledge law teachers produce is intrinsically political and actually effective in our political system. In short, legal knowledge is ideological.20

A second basic idea is that we should be a culturally pluralist society that deliberately structures institutions so that communities and social classes share wealth and power. The sharing of wealth and power that occur automatically, so to speak, through the melting pot, the inarket and ineritocracy are not enough, according to this notion. At a ininimuin, cultural pluralisin means that we should structure the coinpetition of racial and ethnic commumities and social classes in markets and bureaucracies, and in the political systern, in such a way that no coinmunity or class is systematically subordinated. ${ }^{21}$

From these two ideas, I draw the conclusion that, completely independently of "merit" as we currently determine it, ${ }^{22}$ there should be a

19. Id. at 1807 .

20. See The Politics of Law: A Progressive Critipue (D. Kairys $2 d$ ed. 1990); D. Kennedy, Form and Substance in Private Law Adjudication, 89 HARv. L. Rev. 1685 (1976) [hereinafter D. Kennedy, Form and Substance]; D. Kennedy, The Structure of Blackstone's Commentaries, 28 Buffalo L. Rev. 209 (1979); D. KenNedy, Legal EduCATION AND tHE REPRODUCTION OP Hierarchy: A Polemic AGainst THE System 14-32 (1983).

21. See Freeman, Legitimizing Racial Discrimination, supra note 1; Colker, Anti-Subordination Above All: Sex, Race, and Equal Protection, 61 N.Y.U. L. REv. 1003 (1986); R. Kennedy, Persuasion and Distrust: A Comment on the Affirmative Action Debate, 99 HARv. L. REv. 1327, 1335-36 (1986) [hereinafter R. Kennedy, Persuasion and Distrust]; R. Kennedy, McCleskey v. Kemp: Race, Capital Punishment, and the Supreme Court, 101 HARV. L. REv. 1388, 1424 (1988); C. MACKINNON, FEMinism Unmodified: Discourses on LiFE AND LAW 32-45 (1987); Olsen, Statutory Rape: A Feminist Critique of Rights Analysis, 63 TEx. L. REv. 387, 390-401, 429-30 (1984); Ansley, supra note 5, at 1063-64.

22. "Independently of 'merit" " means regardless of whether the candidates in question would be hired or promoted if the law schools applied their current standards without taking affirmativc action goals into account. I put the word "merit" in quotation marks because, in my twenty years as a law school faculty member, I have quite consistently found myself voting "on the merits," without regard to affirmative action, for minority teaching candidates who did not get the job and against 
substantial representation of all numerically significant minority cominunities on American law faculties. The analogy is to the right to vote, which we refuse to distribute on the basis of merit, and to the right of free speech, which we refuse to limit to those who deserve to speak or whose speech has merit. The value at stake is community rather than individual empowerment. In the case of affirmative action, as im those of voting and free speeeh, the goal is pohitical, and prior to the achievement of enlightenment or the reward of "merit" as determined by existing institutions.

Race is, at present, a rough but adequate proxy for conneetion to a subordinated community, one that avoids imstitutional judgments about the cultural identity of particular candidates. I would use it for this reason only, not because race is itself an index of merit, and in spite of its culturally constructed character and the arbitrariness involved in usimg it as a predicter of the traits of any particular individual. My argument is thus addressed to only one of the multiple forms of group subordination, though it could be extended to gender, sexual preference, social class, and ethnicity withni the "white community."23

The poitical argument includes the idea that minority communities can't compete effectively for wealth and power without intelligentsias that produce the kinds of knowledge, especially pohtical or ideological knowledge, that will help them get what they want. To do this, they need or at least could use some number of legal academic jobs. It also includes the idea that cultural diversity and cultural developinent are

white candidates who did. This means that I disagree with my own school's institutional application of the merit standard before we even get to questions of affirmative action. Extensive indirect exposure to hiring and promotion decisions at a range of other schools suggests to me that they are not different. I would say most law school faculties give too much weight to paper credentials, overvalue old-boy conneetions, make bad intuitive judgments based on interviews, and tend to misevaluate the substantive quality of presentations and written work when applying formally colorblind standards. For these reasons, the current institutional interpretation of standards yields no more than a very loose approximation of what I myself regard as inerit. For a somewhat different but I think accurate critique of ehte law school hiring, see Carter, The Best Black, and Other Tales, 1 Reconstruction 6 (1990). For a critique of Carter, see infra Part IV. D. See also Bartholet, Application of Title VII to Jobs in High Places, 95 HARv. L. REV. 945 (1982).

23. Cf. Appiah, The Uncompleted Argument: Du Bois and the Illusion of Race, in "RACE," WRITING AND DIFFERENCE 21 (H. Gates ed. 1986). I see the groupings that Amerieans identify as "racial," such as the black, Hispanic, Asian-American, or Native American communities as different from communities characterized as "ethnic," such as the Irish-American, Italian-American, etc. The difference I am asserting derives not from the biology of group members, but from their different places in the American ideology of racial and group identity and from the historic practice of differential treatment in the context of subordination. See W. JORDAN, THE WHITE MAN's BuRdEN: Historical Origins of Racism in the UnIted States (1974); G. Fredrickson, White Supremacy: A CoMparative STUdy IN AMERICAN AND SOUTH AFricaN History (1981); $\mathbf{N}$. Gotanda, supra note 11 . 
good in theinselves, even when they do not lead to increased power for subordinated communities in inarkets and political systeins.

The political case is coinplicated by the fact that when law faculties distribute jobs in legal academia, they do inore than distribute wealth and the power to participate in pohtics through the production of ideology. They also distribute power to influence who will participate in the future, because those they choose will vote on those decisions. In deciding who to hire or promote according to colorblind criteria, law faculties make culturally and ideologically contingent judgments about what candidates are most promismg or deserving, and about who should make these very judgments in the future. Given the ideological and cultural cliaracter of these clioices, and their (limited but significant) political impact, white males have no more business monopolizing the process of distributing the benefits than they lave monopolizing the benefits themselves. ${ }^{24}$

A serious obstacle to this proposal is the "pool problenn."2s The nuniber of minority teaching candidates is limited, and the prospects for the future are clouded by the decline in the number of black college graduates. (The situation is different for eacls cultural commumity.) I would therefore limit affirmative action by imposing a floor or cut-off point in the form of a requirement of minimuni actual or anticipated competence in performing the instructional function of a law professor. ${ }^{26}$

24. This is not a "reparations" argument for affirmative action, since it is not dependent on establishing for any particular cultural community that a history of racial oppression justifies special measures in the present. The idea is that if the politically dommant groups decide to annex, transport, or admit into the United States large nunibers of people who form a subordinated cultural community, then they should make sure those people have the resources to function in the national political arena. But the argument is not averse to reparations, and I favor them where there has been a history of oppression. For a reparations argument, see Matsuda, Looking to the Bottom, supra note 4.

25. See R. Kennedy, supra note 3 , at $\mathbf{1 7 6 5 - 7 0 . ~}$

26. Incorporating a floor into the proposal ineans that faculties that decide to adopt it will have to negotiate over what should be considered minimum qualifications. If a faculty set the floor very high, the result would be little clange in existing practices, since all but the eandidates who would have been considered anyway would be excluded. For the proposal to have an impact, the faculty adopting it would lave to intend to change its practices by identifying a significant pool of candidates of color considered minimally qualified, and then choosing "the best" from among them until the faculty had achieved a reasonable representation of minorities. The terms "reasonable representation" and "minimun qualifieations" are vagne, but this does not seem to me a drawback to the proposal. We are talking about clianges at the level of particular law faculties rather than about legislation or administrative or even Association of Ameriean Law Schools (AALS) gnidelines. No faculty would adopt the proposal unless there was a majority committed to a quite radical change in existing practices. That majority could clioose to define the new policy much more specifically, say in terms of quotas and hists of credentials, rather than leave it vague. But another faculty might see the vagueness of the standard as valuable for "equitable flexibility" rather than viewing it as a drawback. 
It would seem to me a problem (requiring tradeoffs) if the implementation of this view would be unfair to individual whites excluded from teaching jobs, or if it would lead to a decline in the quality of legal scholarship. But I believe that massive affirmative action would not be unfair to excluded whites, and that it would improve the quality of legal scholarship as I assess it. It would also liave, I think, a beneficial effect on the quality of life, by undermining the fetishistic, neurotic and just plain irrational attitude toward "standards" and merit-based "entitlement" that prevails in legal academia.

\section{B. Affirmative Action and the Quality of Work}

The standards that law sclools apply in deciding who to hire and who to promote function to exclude scholars from cultural communities with a history of subordination. Because we exclude them, we get contributions to legal knowledge from only a small nuniber of people witl ties to those communities. I beheve that if there were a lot more such people, they would make contributions that, taken as a wliole, would have a culturally specific character. Judging by my own culturally and ideologically contingent standards, I think they would produce outstanding work not otherwise available. Law schools would do better to invest resources in evoking this contribution than in the fungible white male candidates at the margin who get jobs under the existing selection systems. (Though quite a few who appear marginal turn out to be terrific.)

I don't mcan that there would be a minority "line." But there would be a variety of positions, debates and styles of legal academic writing that everyone would identify as resulting from the rise of mimority legal culture. Some of these debates, positions and styles would be produced by whites, but no less a product of cliange in the racial inakeup of the academy. Some of the new work would certainly look wrong or mediocre to me. But some would knock our socks off, in unexpected ways and in ways already presaged by Critical Race Theory. ${ }^{27} \mathrm{I}$ liave no doubt that in terms of the social and intellectual value of scholarly output, legal

The floor, as I define it in the text, refers only to instructional functions of the law professor. I would leave writing out altogether, for at least three reasons. First, existing criteria of inerit do not seem to ine either to predict or to reward ex post the particular qualities that make for what I regard as scholarly excellence. Second, arbitrariness and ideological disagreenent about what scholarship is good scholarship chill the academic freedom and undermine the quality of life of candidates and assistant professors. Third, since the rationale of the proposal is partly political empowerment of cultural communities that are subordinated by the dominant white community, it is undesirable to invite the white male majorities of our law faculties to engage in exclusion from the pool of "minimally qualified" scholars of color according to criteria of "quality" that have a heavy ideological load.

27. See supra notes 4 \& 5 . 
academia would be better off than it is now. We have lost a lot by preventing minorities from making this contribution. We can't get it unless we give them the resources, in the form of legal academic jobs, to make it.

Second, I think soine legal scholarship is exciting and enriching and stimulating, but that's not very much. People seem to produce the good stuff through neurotic, often dramatic processes, full of twists and turns and surprises. I think most legal scholarship is pretty much done by the numbers, and it's hard to inake any sharp quality differential between articles. This stuff is useful. Writing it is hard work. But it doesn't take deep scholarly quality. There are many, many people who are excluded by the "standards" froin teaching law who could do it as well or as mediocrely as those who do it in fact. For this reason, I think we would lose little in the way of quality even if massive affirmative action failed to produce the rich harvest of new ideas and approaches that I anticipate.

The possibility of (dramatically) improving legal scholarship provides a second strong reason for a massive affirmative action program. It is not just that there is no trade-off between quality and affirmative action. The existing system demies us a benefit. Even in the absence of the pohtical justification, I would favor a new system on this ground. ${ }^{28}$

\section{Affirmative Action and White Entitlements}

Suppose a law faculty adopts this version of affirmative action because it hopes to improve the quality of legal acadeimic work, as well as because it is pohitically more just. When the faculty prefers a minority job applicant over a white even though the present system would give the job to the white, it does so, in part, because it thinks that in the long run this approach will improve scholarship and teaching. We are treatimg race as a credential (as a proxy for culture and commumity) because we

28. Yet a third important reason for affirmative action is that it will improve the quality of legal pedagogy. The political case anticipates that increasing the number of law teachers of color will influence the experience of law students of color in directions that will empower subordinated coinmunities. This is a part of the general strategy of building minority intelligentsias so that subordinated communities can participate effectively in the political process. The cultural case anticipates that scliolars of color will liave an impact on the substantive content of what is taught about particular legal issues and on the coinposition of the curriculuin and on the syllabi of particular courses. In all these areas, "white moderate" bias is rampant, by whicl I mean that white moderate ideological blinders render minority issues invisible. But affirmative action is also important to improve the educational experience and the practical value of legal education for people of color. The availability of "role models" is ouly a part of what is at issue here. Improvements should derive in part directly from what minority teacliers do in and out of the classroom, and in part from their influence on what white teachers do. And the benefits slould run to white students as well as to students of color. See Crenshaw, Foreword: Toward a Race.Conscious Pedagogy in Legal Education, 11 NAT'L BLACK L.J. 1 (1989); cf. Lopez, supra note 5. 
anticipate terrific work from some of these applicants, work that we don't think we can get from the whites they replace. The reason we don't expect it from them is that we believe that work from authors with ties to subordinated communities is likely to have different excellent qualities from work from inside the dommant community.

Are the excluded whites "entitled" to prevent this improvement in scholarship? I would say they are not. Even if all the colorblind criteria of academic promise that we can think of favor a white candidate, he or she lacks something we want in some substantial nuniber of those we will hire. He or she has less promise of doing work with the particular strengths likely to derive from connection to a subordinated cultural community.

The white male law teaching applicant whose resunie and interviews would get him the job were it not for affirmative action has indeed accoinplished something, and will not be rewarded for it with the job. But if he understands in advance that the terms of the competition are that he is competing against other white males, for the limited nuniber of slots that a pohtically just system makes available to people who have had his advantages, then I don't think he has any reason to complain when a job he would have gotten under a different (less just) systein goes to a mimority applicant. But the excluded white candidates do not have as strong a claim as assunied above.

First, those who win out in the existing system have no claim to be "the best," even according to the colorblind criteria, because the underlying systems of race and class and the system of testing excludes so many potential competitors from the very beginning. The competition in which our teaching applicants and tenure candidates win out is restricted, with only a tiny nuniber of notable exceptions, to people born within a certain race-class distance of those positions. At every step, the differences in educational resources and the testing process screen out millions of people who 1might be able to do the job of law professor better than those who end up getting it. As against those excluded from the coinpetition by race and class and the vagaries of the testing system, those who win out have only a very limited claim of entitlement.

Second, the "standards" that law schools apply in hiring assistant professors and promoting them to tenure are at best very rougli proxies for aceomphishinent as we assess it after the fact. People who get good grades and have prestigious clerkships often turn out to be duds as legal scholars and teachers by the standards of those who appointed them. People with less impressive resumies often turn out to be terrific scholars and teachers. People who get tenure on the basis of an article that looks good to the tenure committee (and those of the facnlty who read it) often 
never produce anything of comparable quality again. "Entitlements" based on these rough proxies are worthy of only limited respect. The white males who would be displaced to make way for large numbers of minority scholars would be hurt, but not in a way that would be unfair, given the importance of the goals to be achieved.29

Third, law school faculties apply a pedestrian, often philistine cultural standard in judging white inale resumes, interviews and presentations at the entry level, and white male teaching and tenure work at the proinotion level. They administer this pedestrian, philistine standard with an unconscious but unmistakable moderate conseryative to moderate hiberal bias. And they serve it up with a powerful seasoning of oldboyisin and arbitrary chique preference as between white males. This doesn't mean a inore pluralist academy would necessarily do better or produce inore pohtical diversity. It does mean for me that there is an eleinent of laughable exaggeration in the claims often inade for the ineritocratic purity of existing arrangements. The people who would win out in this systen were it not for affirmative action have weak claims of unfairness just because they are not so wonderful, even by comparison with other white males, that they can regard themselves as ninocent victims.

29. The mainly white male candidates who win jobs and tenure under the existing system do so through a difficult, effortful, often draining process of academic competition, before and during law school. The criteria of success, mainly getting good grades on exams, writing good student papers, and making professors think you are intelligent and "sound" (not too far out of the political mainstream) have real bite. I do not see them as arbitrary in the sense that there is enormous variance in how different professors evaluate a given student, or that just anyone can do equally well, or that grades are random. But the fact that there is a difficult process of seleetion does not mean we should regard those who get through the screening as having "merit" that "entitles" them to the jobs we offer.

The undergraduate and law school work that qualifies students for jobs usually has no academic "merit" in the sense of making permanent contributions to knowledge. Its function is to develop skills that will pay off, if they do pay off, later on. Possession of the skills is no guarantee of success, and people who have less skill at the competition often produce better work in the end than thosc with inore. The academic performances that get one into law school and then into the legal academic job market are at best a weak proxy for the merit of actually producing valuable legal scholarship or teaching.

Even the criteria we apply in granting tenure are no inore than proxies for merit in the lifetime careers we are distributing. We grant future job seeurity on the basis of past performance, without subsequent readjustment if the candidate turns out to lack merit over the coining decades. We do reward actual academic merit, but we do it through the process of lateral appointment up the prestige ladder, through the distribution of high reputation and by academic honors and prizes.

In short, the white male applicant is in a very different situation than the white male author of a law review article rejected because the editors accepted an article by a black that has no clain to cultural distimctiveness and is "not as good" by colorblind standards as his. Even in this case, the decision may be justified as an investment by the white community in developing miuority scholars who may eventually use the resources generated by publication to produce distinctive work, and as the distribution of a share of the social power represented by publication to people who have traditionally been excluded. But the case is harder because we are dealing with a direet judgment of scholarly merit rather than with a proxy. 
There is no trade-off between racial justice and legal academic quality. Indeed, both goals point in the same direetion. There is no claim of entitlement against these goals even for candidates who are plausibly the best by every colorblind criterion. The actual candidates likely to be rejected have claims weakened by exclusion of competitors, especially coinpetitors from the groups that would gain by affirmative action. Their claims are further weakened by the fact that their accoinplishments are inere proxies for legal academic merit, and by the low cultural quality and arbitrary subjectivisin of the screening systein that would otlierwise liave delivered them the goods.

\section{Destabilizing Attitudes about Race and Merit}

It would be a beneficial side effect of massive, politically and culturally grounded affirmative action if it upset or destabilized the way most law teacliers experience the whole issue of merit, and especially its relationship to race. One of the least attractive traits associated with fundamentalism is the tendency to fetishize "credentials" that are ouly proxies for actual achievement. See the case of the academic who wants the law scliool transcript of a candidate for a teaching job wlio is thirty-five years old and lias written four law review articles and taught several thousand law students.

But this is just tlie extreme case. We are generally too dependent on, even addicted to, the continual reward of being told we are better, and that our law schools are better, according to an objective merit scale, than otlier people and law scliools. And as a group we are excessively susceptible to mjury by judgments tliat we fall below otliers. Addictive concern witl pellets of ineritocratic praise and blaine manifests itself in neurotic vices.

The most striking of tlese is resentment, intense preoccupation with the ways in which one lias been unjustly demed tlie praise or job or honor that one's "inerit" "entitles" one to, and witli the ways in whicli otlers have received inore than their due. A second vice is careerisin or opportunism, in whicls an interest in chmbing tlie ladder or inaximizing one's academic capital coines to dominate attachment to any set of ideas or any set of autonounous judgments about others.

On the flip side, obsession with merit funnels emotional energy into generating distinctions tliat will justify the claim that differences in people's rewards and punishments are deserved ratlier than arbitrary. Sometimes we just can't admit tliat our standards lack power to inake tlie distmctions that law school roles require of us, among students or job applicants or tenure candidates. Intensely debated but meaningless small distmctions at the inargin allow us to miagine that merit is ruling the 
day, so that no one has been wronged, when the distinctions that have real meaning are too crude to do the job.

Sometimes what we are denying is that merit is only part of the story of colleagueship. The torturing of standards until they confess that "he got what he deserved" may be a cover-up for other motives. The hypertrophy of standards-talk also has a narcissistic payoff, since it endlessly reaffirms the merit of those who make judgments of merit. ${ }^{30}$

Affirmative action has already somewhat destabilized these neurotic patterus. They might be further jarred by an explicitly political and culturally based increase, because everyone involved in the enterprise would be forced to recognize a degree of relativity to the idea of merit. Dissociating some hiring and promotion decisions from any particular set of credentials undermines everyone's sense that their true being is their academic capital.

A political move to large scale affirmative action would say to minorities, "Here is a part of the resources. Do what you can with it." It wonld free whites from some of the political obligation that coines of unjust treatinent of minorities. It wonld reduce the nagging sense that our ability to assess merit is consciously or unconsciously corrupted because we now aecomplish limited power and wealth sharing through acadelmic decisions on hiring and promotion.

It would reduce the sense that we coerce minorities who want the rewards we have to offer into "being like us." It would also increase integration, the chance for more relations with minorities in our own workplaces. But it would do this without presupposing that our "merit" joins us together in a way that is "more important than" or "independent of" cultural cominunity. In short, it might promote integration while undermining the ideology of colorblindness.

There are obvious dangers. The proposal might imcrease the stereotyping of minorities as intellectually inferior. It miglit lead to protracted, destructive racial conflict between majority and minority groups on faculties, and within those groups. It might be impossible to desigu a scheme of wealth and power sharing that wonld be easy to administer so as to avoid endless conflict about how to define it in practice. I don't deny these dangers. I just think them worth risking, given the possible benefits.

The proposal obviously contemplates race-conscious decisionmaking as a routime, non-deviant mode, a more or less permanent norm in

30. That these vices are widespread does not invalidate meritocracy. They may be present in valuable meritocratic systems and in corrupt ones, or largely absent in either type. I am asserting that they are distressingly prevalent in our system and constitute a significant cost of doing business the way we do. 
distributing legal academic jobs. A "racial distinctiveness" theory (actually cultural distinctiveness) coinbined with race-conscious decisionmaking is "assimilated into our conception of meritocracy,"31 which is just what Kennedy's article urges us to avoid at all costs. The position is probleinatic as well as controversial, because it rehes on the idea of cultural subordination, rather than on the more familiar fundamentalist ideas of prejudice and discrimination. ${ }^{32}$

\section{The Cultural Subordination Thesis}

The issue is whether there is enough cultural distinctiveness, and enough subordination and exclusion, so that we must treat representation in academia as a pohtical question, and so that we can expect major intellectual gains froin doing so. ${ }^{33}$ The argument thus far has been largely hypothetical. Even if one accepted the value of the notions of culture and ideology, one might deny that, $\mathrm{i}$ the actual conditions of the United States in 1990, cultural and ideological differences are significant. Or one might merely deny that they are large enough so that we need to structure law schools to take then into account. ${ }^{34}$

The cultural pluralist position to the contrary rests on a whole complex of ideas about American society. I anı going to introduce them in

31. R. Kennedy, supra note 3 , at 1807 .

32. It is an interesting question, but one I will not deal with in this Article, whether the proposed program violates the equal protection clause of the United States Constitution or Title VII of the Civil Rights Act of 1968, as they are currently interpreted by the United States Supreine Court. See D. Bell, The Racial Barrier to Reparations, in AND WE ARE NOT SAVED supra note 4, at 12339. See generally Sullivan, Sins of Discrimination: Last Term's Affirmative Action Cases, 100 HARV. L. REV. 78 (1986) (arguing that affirmative action can be justified with "forward-looking" goals of an integrated future rather than solely for past sins); Brest, Affirmative Action and the Constitution: Three Theories, 72 IowA L. REV. 281 (1987) (analyzing "original intent," "discrete and insular minorities" and "color-blind equality" approaches to affirmative action).

33. The tone of Kennedy's article is unrelentingly hostile to the "racial distinctiveness" thesis, but surprisingly unhelpful in assessing it. He writes as if it must unean either that there is a single uninority or black or Hispanic "voice," or that anything any minority person says is said in a minority voice. He suggests (note irony) that we should develop a definition of what a ineritorious black voice is, and then apply colorblind criteria in judging whether candidates have it, or that we should just abandon the idea altogether. See R. Kennedy, supra note 3, at 1802-03. As indicated in the text following this note, the issue seems to ine a good deal nore coinphicated than his position makes it seem.

34. Randall Kennedy, and I think anost others of his camp, is not willing to go that far. At a nunber of points, his article recognizes, tentatively, one might even say grudgingly, that the groups that make up our society have differing characteristics and that under some circumstances it might inake sense to take thein into account:

[E]ven taking into account class, gender, and other divisions, there night renuain an irreducible link of commonality in the experience of people of color: rich or poor, male or feniale, learned or ignorant, all people of color are to soine degree "outsiders" in a society that is intensely color-conscious and in which the hegemony of whites is overwhelming.

Id. at 1784 . 
highly schematic form. Together they define a variant of the "nationalist" ideology. ${ }^{35}$

\section{A. Premises of Cultural Pluralism}

Groups exist in a sense that goes beyond individuals having similar traits. People act together, in the strong sense of working out common goals and then engaging in a cooperative process of trying to achieve them. Just as important, they engage im discussion and inutual criticism both about the goals and about what group members are doing (or not doing) to achieve them. This is true of small task-oriented groups (family inembers getting the car packed for a trip), and also of large, diffuse groups, like "the black community," or a law faculty.

An important hunian reality is the experience of defining oneself as "a member of a group" im this strong sense of sharing goals and a discursive practice. Another important experience is being treated by others as a group member. One's interlocutor interprets what one says and does as derived froin a shared project. We all constantly identify groups and their inembers, assuming that we need to in order to understand other people and predict what they will do. ${ }^{36}$

I do not maintain that no appreciable differences exist in the prevailing opinions and sensibilities of various racial groups. Nor do I maintain that it is improper ever to make decisions based on racial generalizations.

Id. at 1816 (footnote omitted). See also id. at $1805 \mathrm{n.271}$ (noting that in some cases the "fact of being black-like that of being tall, being able to see, or siniply being alive-may help one to accomplish something admirable"). There is black hiterature, music, film, in the sense of contributions of individuals who happen to be black, $i d$. at 1758-59, but no "black art" in a stronger sense, id. at 1803 $\&$ n.262. There are patterns of behavior and particular opinions (e.g., opposition to the death penalty, id. at 1816) that characterize one ethnic subculture inore than another. It is even true that "racial and other ascriptive loyalties continue to organize a great deal of social, politieal and intellectual life throughout the world; in many areas such loyalties have intensified." Id. at 1782 (ernphasis added) (footnote ounitted). When talking about the production of academic knowledge, the article places the burden of proof on the person who would assert that ineinbership in a defined community is associated with a particular way of knowing or with particular intellectual strengths or weaknesses. The crucial question in the debate about standards is:

But what, as a function of race, is "special" or "distinct" about the scholarship of minority legal academics? Does it differ discernibly in ways attributable to race from work produced by white scholars? If so, in what ways and to what degrec is the work of colored intellectuals different froin or bctter than the work of whites? ... [A]t least with respect to legal scholarship, [Matsuda] fails to show the newness of the "new knowledge" and the difference that distinguishes the "different voices."

Id. at 1778-79. It seems to me unlikely that we will get far by trying to resolve the substantive dispute by the placement of the burden of proof. If we take the idea of proof seriously, then whocver kears the burden will lose. The decision to allocate the burden to one side or the other is no less ideologieal than a decision on the inerits.

35. Peller, supra note 1.

36. J.-P. Sartre, Critique of Dialectical Reason I: Theory of Practical EnsemBLES (A. Sheridan-Smith trans. 1976). 
Communities are more than mere statistical groupings of individuals with particular traits, but less than self-organized groups. Meinbership presupposes interaction, but the interaction may be sporadic, routine, alienated. A community is an historically specific collection of people with a common past, and a future that will take place on the basis of what has gone before. That basis can be reinterpreted but not obliterated. We are stuck, at any given moment, in the communities we started or ended in, and that is never "just anywhere." Wherever it is, it is both more inert than a self-organized group and less deinanding. The crucial idea is that communities are inade up of living individuals, but they have an eleinent of trans-individual stability and particularity; to be a member is to be situated, and you can be situated only in one or two places at a time. Membership is limiting as well as einpowering.

Communities have cultures. This means that individuals have traits that are neither genetically determined nor voluntarily chosen, but rather consciously and unconsciously taught through community life. Commumity life forms customs and habits, capacities to produce linguistic and other perfornnances, and individual understandings of good and bad, true and false, worthy and unworthy. Culture is first of all a product of community. People living in different groups possess different understandings of value as well as exhibiting different capacities and behavior traits (kinship, cooking, dress). But as I am using it, culture is a characteristic of an individual as well. You can break all your ties to a commumity yet reinain a person witl that community's cnltural identity. ${ }^{37}$

A large part of the population of the Umited States lives in racial and ethnic communities that have a measure of cultural distinctiveness. The distinctiveness coines in part from the origins in Africa, Asia, Europe and Latin America of the different groups that live here. But the cultures of particular communities have becn dramatically transforned by the experience of immigration, forced transportation or annexation, and by the heterogeneous cultural life of this country. Each group has put its culture of origin together with its peculiar circunistances in the United States to produce a distinct set of behaviors, attitudes, beliefs and values. ${ }^{38}$

The racial and ethnic communities of the Umited States are in constant contact witl one another. This contact is asymmetrical. There is a dommant cultural community which is less influenced by and less con-

37. See generally J. Clifford, The Predicament of Culture: Twentieth-Century ETHNOGRAPHY, LITERATURE AND ART (1988).

38. See D. Kennedy, Radical Intellectuals in American Culture and Politics, or My Talk at the Gramsci Institute, RETHINKING MARXISM, Fall 1988, at 100, 129; A. Ross, No RESPECT: INTELlectuals AND Popular CUlture (1989). 
scious of the subordinated groups than they are influenced by and conscious of it. As a result, it is hard to identify any aspect of the cultures of subordinated groups that might be relevant to academic production that has not been influenced by contact with the dominant culture.

The boundaries of cultural cominunities are blurred by the presence of large nunibers of people who can trace their family history back into a subordinated cominunity, but who now regard theinselves and are regarded by others as situated in a culturally intermediate space, or as assimilated to the dominant culture. There are millions of people for whoin the "authenticity" of having always belonged to a relatively hoinogeneous cominunity with an unselfconsciously shared ethos is simply impossible. Most of those likely to benefit by a program of culturallyconscious distribution of academic power and opportunity coine froin these intermediate, inulti-cultural positions. (The existence of this group nay make it more likely that we could actually succeed in implementing cultural diversity.)

Though communities are different in ways that are best understood through the non-hierarchical, neutral idea of culture (some groups do things one way, value one set of things, other groups do it in different ways), some differences are not like that. Americans pursue their collective and individual projects in a situation of group domination and group subordination. By this I mean that we can compare "how well" different groups have done with regard to income, housing, health, education, local and national political power, and access to cultural resources. The groups are not so different that they define these things in radically different ways, or that some groups are just not interested in them. With respect to these cominon measures of equality and inequality, we all recognize that some groups are enormously better off than others.

The experiences of youth within a particular community, or on the border between communities, equip individuals with resources for competition in markets and bureaucracies. Different communities have different access to wcalth and power with which to endow their ineinbers. And the rules of competition in markets and bureaucracies are structured in ways (both formal and informal) that advantage people froin different communities regardless of the resources they bring as individuals to the competition.

Sonie of these advantages are overtly or covertly correlated to the community membership of the people coinpeting. Historically, the white community imposed systenatic race-based discrimination, outright job and housing segregation, and rules that excluded racial minorities and women from directly exercismg pohtical power. In the current situation, particular cultural groups control or dominate some markets and bu- 
reaucracies, and these groups exercise the enormous range of discretionary choice that is inevitable in ways that favor dominant over subordinated communities. Racial and gender discrimination still direct the flow of opportunities and thereby affect the shares groups achieve.

The notion of domination and subordination is ineant to indicate that we cannot understand what happens according to a model in which everyone in the society has innate or individual qualities and individual preferences that they bring into a neutrally structured competitive process that correlates their rewards with their social contributions. There are patterns to the characteristics of the individuals society producesthey are identifiably inembers of the particular communities they grew up in, and their fortunes depend on that fact.

Differences of fortune result from themselves in a circular process. To speak of domination is to say that the group and individual exercise of power given by resources occurs in a competitive struggle im which the better off communities inanage over time to reproduce their advantage by winning enough in each game to reconstitute their stakes. Even the rules of the game are produced by the game, in the sense that power to compete is also power to inodify the rules. The dominant communities are those that have the most resources and rewards, those that inanage to influence the rules that define the game to their advantage, and those that through time manage to reproduce or improve their top-dog position through conipetitive struggle. ${ }^{39}$

The game is cooperative as well as competitive. In order to be rewarded, the meinbers of the different communities have to cooperate across ethnic lines in producing goods and services. There are all kinds of influences and concrete alliances formed, and there are areas and moments when community identity is actually pretty much subnierged im the collective aspects of tasks. Within the communities, there are divisions that are best understood in class terms, and other cross-cutting divisions that represent the community's participation in national life (region, gender, rehigion, etc.). Power and resistance to power pervade the structure. ${ }^{40}$

Though there is a self-conscious ruling class at the top of this structure, neither the class nor the structure fully controls the outcoines and impacts of the game on the communities whose members play it. All the

39. See D. Fusfeid \& T. Bates, The Polttical Economy of the Urban Ghetto (1984).

40. See generally Austin, Employer Abuse, Worker Resistance, and the Tort of Intentional Infiction of Emotional Distress, 41 STAN. L. REv. 1 (1988); M. FoucAuLT, Two Lectures, in PowER/ KNOWLEDGE 78 (1980). On the hounologies in the legal treatment of class and race, see Klare, The Quest for Industrial Democracy and the Struggle Against Racism: Perspectives from Labor Law and Civil Rights Law, 61 OR. L. REv. 157 (1982). 
players are functions of the game, as well as vice versa. There is no "outside position." Communities themselves change internally and through collision with other communities, but the process has as much fate, drift and chance mutation to it as it does mechanical necessity or self-organized group will. Commumities can disperse or assimilate and then re-form, and they can die out or be killed. ${ }^{41}$

The American racial and ethnic communities have intelligentsias, linked in overlapping patterns to a national intelligentsia and to each other. By an intelligentsia, I niean a "knowledge class" working in education, the arts, social work, the law, religion, the media, therapy, consulting, and myriad spim-offs like charitable foundations, for-profit research ventures, and the like. Intelligentsia menibers perform multiple functions beyond their formal job descriptions. In self-organizing groups or individually, some of then work at defining their community's identity (its cultural distinctiveness) or lack thereof, its interests in conlpetition and cooperation with other communities, and its possible strategies. ${ }^{42}$

The national, racial and ethnic intelligentsias are internally divided along ideological lines. One national ideological axis is radical-liberalmoderate-conservative-rightwing. Another is traditional-modernpostnodern. Another is science-social science-humanities-arts. There are also a wide range of ideological debates within particular intelligentsias, for example about their relationship to the national community.

An ideology in the sense in which I am using it is a set of contested ideas that provides a "partisan" interpretation (descriptive and normative) of a field of social conflict.43 The social conflict could be between capital and labor, farmers and banks, men and women, gay and straight, North and South, native born and foreign born, export industries and import industries, or whatever. The concepts that describe and justify the positions of the conflicting groups can be drawn fron almost anywhere, froin philosophy to economics to religion to biology; within the fields that we use ideologically, coniplex systenıs of contested ideas reflect and at the same time influence social conflict. ${ }^{44}$

Ideologists choose their ideas, in the sense that there is no consensus either in their favor or agamst then.. Many people nıay think a particu-

41. See D. KenNedy, The Politics of Hierarchy, in Legal EdUCATION AND THE ReproducTION OF HieRARCHY, supra note 20, at 78-97.

42. See generally A. Gramsci, Selections from the Prison Notebooks (Q. Hoare \& G. Smith eds. 1971).

43. See generally K. MANNHEIM, IdeOlogy AND Utopia: AN INTROduction to the SOCiOLOGY OF KNOWLEDGE (1954).

44. See generally L. Althusser, Ideology and Ideological State Apparatuses (Notes towards an Investigation), in LENIN AND PHLLOSOPHY AND OTHER ESSAYS 127 (B. Brewster trans. 1971). 
lar system is objectively right and many others that it is objectively wrong, or it inay be seen as posing a question you can only resolve by a leap of faith. The most basic critique of the ideologist is that she has chosen her ideas to fit her partisan allegiance, and therefore lacks allegiance to "truth." In the conception of ideology I am using, this must always be recognized as a possibility. People do sometimes distort their intellectual work to serve causes or interests they adhere to. At the same time we have to recognize that where there is social conflict and contested interpretations of that conflict, there is no intellectual space outside of ideology. Intelligentsia virtue consists not in "objectivity" or "neutrality," which are impossible once there is ideological division, but in the attempt to einpower an audience to judge for itself.

It follows that being an ideologist doesn't mean being closed minded, or uninterested in questioning fundamental assumptions, or being blind to evidence that contradicts those assumptions. In this sense of the term, one is in the position of the ideologist just by virtue of having, at any given moment, made choices between contested views that influence the intellectual work one does (and are influenced by it). "Moderates" are ideologists because when they call themselves that they implicitly appeal to a controversial critique of "ideologues." (This is the ideology of moderation.)

Meinbers of minority intelligentsias are linked to their cnltural communities in various ways, and divided from them as well, usualiy by social class, income, intelligentsia interests, and links to the national intelligentsia and cnlture that are different from those of the "inasses." A basic ideological conflict is over how to describe and evaluate the courses of conduct that intelligentsia members adopt in this situation. There are ideologies of assimilation and of authenticity, of group accommodation and of group resistance, of mdividual self-realization and of collective obligation, and so forth.

The existence of ethnic intelligentsias, their size, and the power they produce for commumities, all depend on access to resources, as does their ability to contribute to national intellectual/pohtical life. One index of a cominunity's cultural subordination is dependence on others to produce knowledge in areas where it would seem, at least superficially, that cominumity interests will be affected by what that knowledge is. Another is inability of its intelligentsia to influence the national intelligentsia, and indirectly the American mass culture audience on issues of importance to the cominunity. 45

45. Some important discussions of the role of intellectuals in situations of domination are $P$. Freire, Pedagogy of the Oppressed (M. Ramos trans. 1970); F. FANON, The Wretched of 
The above definition of cultural subordination is patently ideological. The conceptual scheme proposed is only one of many available to describe and judge the status of an intelligentsia, and within each scheme there is a well developed critique of its rivals.

\section{B. What Might Be Gained Through Large-Scale Affirmative Action}

Against this background, I would deny the existence of a "black point of view" or a "black voice" in any essentialist (or racialist) sense. ${ }^{46}$ But that doesn't answer the particular questions that are relevant to the political and cultural arguments for large scale affirmative action. The first of these is whether minority communities would get, froin a inuch larger minority legal intelligentsia, a scholarly output that would better serve their diverse political, social and economic interests than what they get froin an overwhelmingly white legal intelligentsia. The second is whether the legal academic cominunity as a whole would get a inore valuable total corpus of scholarship.

I see two likely changes in this regard. A unuch larger minority intelligentsia should produce more scholarship about the legal issues that have impact on minority communities. The subject inatter of scholarship is determined at present by the unregulated "interest" of academics. What we decide to write about just "flows naturally" from our backgrounds, education and individual peculiarities. I think it is obvious that soine significant proportion of minority intellectuals would be led im this way to write about minority legal issues ${ }^{47}$

The precedent for this is the creation of nodern civil rights law by black lawyers who devised the hitigation strategy of the National Association for the Advancenient of Colored People. It would be farfetched to argue that the race of these lawyers was irrelevant to their choice of subject inatter, or that the black civil rights cause wonld have evolved in the same way had all the lawyers nivolved been white. ${ }^{48}$

Along with more scholarship on minority issues, there should be 1nore scholarship on the implications for minorities of any issue currently under debate. In other words, Hispanic scholars working on the purest

THE EARTH (C. Farrington trans. 1968); E. FRAZIER, BLACK BOURGEOISIE (1957); H. CRUSE, THE CRISIS OF THE NEGRo INTELLECTUAL (1967).

46. Harris, Race and Essentialism in Feminist Legal Theory, 42 STAN. L. REv. 581 (1990).

47. For an example of the kind of work I am talking about see Harold McDougall's articles about the Mt. Laurel decision. McDougall, The Judicial Struggle Against Exclusionary Zoning: The New Jersey Paradigm, 14 HARv. C.R.-C.L. L. REv. 625 (1979); McDougall, Mt. Laurel II and the Revitalizing City, 15 RuTGERS L.J. 667 (1984); McDougall, From Litigation to Legislation in Exclusionary Zoning Law, 22 HARV. C.R.-C.L. L. REV. 623 (1987).

48. See M. Tushinet, The NAACP's Legal Strategy Against Segregated Education, 1925-50 (1987). 
of corporate law questions within the most unquestionably Anglo scholarly paradigm are still, I think, more likely than white scholars to devote, over the long run, some time to thinking about the implications of law in their chosen technical area for the Hispanic communities. ${ }^{49}$

The second anticipated change is crucial to my argument. Along with a quantitative change in the focus of scholarship, it seems likely that an increase in minority scholarship would change the framework of ideological conflict within which issues in the race area but also in other areas are discussed. I do not mean by this that there is $a$ black (or other minority) ideology. The point is rather that there are historic, already established debates within the mimority intelligentsias that are obviously relevant to law, but that have been largely absent from legal scholarship.

Here are some examples of debates in the black intellectual community that have only begun to get played out and transformed in law: between nationalists and integrationists, ${ }^{50}$ between progressives and conservatives, ${ }^{51}$ between those who see current racisin as a more or less important determinant of current black social conditions, ${ }^{52}$ and between black feminists and traditionalists. ${ }^{53}$ The nationalist versus integrationist

49. An example of the kind of work I am talking about is Baeza, Telecommunications Reregulation and Deregulation: The Impact on Opportunities for Minorities, HARV. BLACKLETTER J., Spring 1985 , at 7.

50. I am referring here to the century and a half long discussion about the character of African American identity and its implications for strategy. The debate involves famous pairs, among them Martin Delany, see The Condrion, Elevation, Emigration, AND Destiny of The Colored People of THE UNITEd STATES (1852), and Frederick Douglass, see MY Bondage AND MY Freedom (1855); Booker T. Washington, see The Future of THE AMERICAN Negro (1899), and W.E.B. Du Bois, see The Souls of Black Folk (1903); Marcus Garvey, see E. Cronon, BlaCK

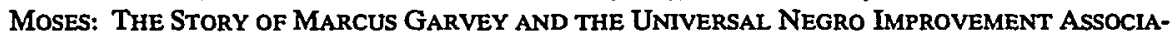
TION (1957), and the later W.E.B. Du Bois, see DusK OF DAWN: AN ESSAY TOWARD AN AUTOBIOGRAPHY OF A RACE CONCEPT (1940); E. Franklin Frazier, see BlACK BourgeoIsIE (1957), and Harold Cruse, see THE CRISIS of THE NEgro InTEllectuAl (1967); Malcolin X, see THE AUTOBIOGRAPHY OF MALCOLM X (1965), and Martin Luther King, Jr., see A TESTAMENT OF HopE: The EssentIAI Writings of MarTin LUTHER KING, JR. (J. Washington ed. 1986). This list is just an appetizer. The primary and secondary literatures are enormous. A valuable summary and reinterpretation is C. WEST, The Four Traditions of Response, in PROPHESY DELIVERANCE!: AN Afro-American Revolutionary Christianity 69 (1982). See also R. Allen, Black AwakENING IN CAPITALIST AMERICA: AN ANALYTIC History (1969). For an extensive collection of sources, see Peller, supra note 1.

51. See T. Sowell, MARKeTs AND Minorities (1981) and T. Sowell, RAcE AND EconomIcs (1975). For a progressive critique of Sowell, see Crenshaw, Race, Reform and Retrenchment, 101 HARV. L. REV. 1331, 1339-46 (1988).

52. See W. Wilson, The Truly Disadvantaged: The Inner City, the Underclass, and Public Policy (1987); W. Wilson, The Declining Significance of Race?: A Dialogue Among Black and White Social Scientists (1978); See R. Kennedy, supra note 3, at 1814 n.296.

53. For a classic statement of the conflict, see Z. N. HURSTON, THEIR EYES WERE WATCHING God (1937). See generally P. Giddings, WhEN ANd WhERE I ENTER: The IMPACT OF Black WOMEN ON RACE AND SEX IN AMERICA (1984); B. HoOKS, AIN'T I A WoMAN: BLACK WoMEN 
and gender debates are now for the first time beginning to get a hearing as a result of the presence of more minorities in the legal academy..$^{54}$ There are similar debates im the other minority cominunities. ${ }^{55}$

\section{The Cultural Case in the Context of Cultural Subordination}

It comes down to a question of value. I have come (belatedly) to the view that American culture and pohitics are rendered radically more imtelligible when viewed through the lens that intellectuals of color have constructed over the years. There is more in this general literature than any one person can assimilate. But there is nowhere near as much legal scliolarship as there ought to be. Scliolars with ties to subordinated communities are uniquely situated in respect to these ideological resources, and more likely than white scliolars to mobilize them to contribute to our understanding of law-im-society.

They are uniquely situated because, "even taking into account class, gender, and otler divisions," there does indeed remain "an irreducible link of cominonality in the experience of people of color: ricl or poor, male or female, learned or ignorant, all people of color are to some degree 'outsiders' in a society that is intensely color-conscious and in whicli the liegemony of whites is overwlielming." 56 The ideological literature of subordinated communities comes out of this experience, in all its variants, and is'addressed to it. The flowering in legal scliolarship of this literature combined witl these experiences is just not something we can plausibly expeet from white scholars.

Again, tlie resources are not Truths to which only people of color have access (tliough, wlio knows, there may be some of them), but de-

AND FEMINISM (1981); see also L. RAINWATER \& W. YANCEY, THE MOYNIHAN REPORT AND THE Politics of Controversy (1967); H. Cheatham \& J. Stewart, BlaCK FamiLIes: InterdisCIPLINARY PERSPECTIVEs (1990).

54. Derrick Bell's point of view has always contained elements of nationalisn-particularly his writing on school desegregation. Bell, Serving Two Masters: Integration Ideals and Client Interests in School Desegregation Litigation, 85 YALE L.J. 470 (1976) (educational inprovement for blacks must take precedence over failed integration policies); Bell, The Burden of Brown on Blacks: History-Based Observations on a Landmark Decision, 7 N.C. CENT. L.J. 25, 26 (1975) (recognizing Brown's limitations and arguing that it should be used as "critical leverage for a wide range of [continuing] efforts" by black communities to improve education for blacks). The debate is internal to Bell's book AND WE ARE NoT SAVED, supra note 4. With the publication of the articles cited in supra notes 4 and 5, and the response in R. Kermedy, supra note 3, the issue seems finally to have its own moinentum within legal scholarship. On black feminisin in law, see Crenshaw, Demarglnalizing the Intersection of Race and Sex: A Black Feminist Critique of Antidiscrimination Doctrine, Feminist Theory and Antiracist Politics, 1989 U. CH. LEGAL ForUM 139; Harris, supra note 46.

55. For example, compare R. RODRIGUEZ, HUNGER OF MEMORY: THE EDUCATION OF RICHARD RodRIGUEZ (1982) with A. MIRANDE, GRINGo JUSTICE (1987).

56. R. Keimedy, supra notc 3, at 1784. Kennedy's article says only that there "might" be a hink of commonality among people of color. $I d$. 
bates involving all the complexity of incompatible conceptual frameworks and flatly contradictory conclusions. They relate the internal dialectics of subordinated communities, and the dialectic of their interaction with the United States at large. They are open to nultiple interpretations, including specifically white interpretations. For this reason, a substantial increase in the number of minority scholars should also improve white scholarship.

An increase in scholarship that takes seriously the issues that have been raised by the black intelligentsia would have relevance to the debates in legal scholarship about gender, sexual orientation and class. Indeed, I find it hard to think about, say, the separatist or culturalist strand in modern feminisin without relating it to the debate about racial identity with which it is intertwined. The historical influence of black biberation thought on all other forms of late 20th century American theory about subordinated groups has been enormous. But the influence has been indirect im legal thought, in part because of the small size of minority legal intelligentsias. Wherever groups are in question, whether in corporate law or in family law, or in the law of federalism or local government law, the historic minority debates and their contemporary extensions should have an impact on sophisticated mainstream thinking.

The issue is not whether there should be a cultural bias in judging actual work. When we have the work before us, there is no reason not to consult it and decide for ourselves, imdividually, who has produced knowledge of value to us. In judging value to us, the cultural status of the producer is irrelevant, and so is the "nierit" of the producer. In and of themselves they neither add nor subtract value, though knowing the author's status and accomplishment can change our understanding of a work and allow us to find value $i$ it that we would otherwise have missed. This knowledge can also mislead us. There is no way to eliminate this risk, since as I will argue in the next Section, we can understand and assess the work only as a text situated in some presupposed cultural and ideological context, and assess it ouly from our own particular cultural and ideological situation.

There is nothing that precludes white scholars from inaking the contributions anticipated from scholars of color. An outsider may learn about a culture and its debates and produce work about or even "within" them that is "better" than anything an insider has produced. There are advantages as well as disadvantages to outsider status, and everyone im a multi-cultural society is simultaneously inside and outside. And there is nothing to guarantee that minority scholars will choose to or be able to make those contributions. They may squander their resources, or decide to do work that is imdistniguishable in subject nıatter and approach fronı 
that of white scholars. But their track record, with and without affirmative action, has been good enough, easily, even as tokens, to sustain a prediction of excellence to come.

\section{The Political Case in the Context of Cultural Subordination}

Through scholarship focusing on their own concerns and through ideological debate played out in the legal arena, minority cominunities (through their intelligentsias) develop themselves internally, assimilate for their own purposes the resources of the culture at large, and build power for the competitive struggle with other groups. The power to create this kind of knowledge is political power. Therefore it should be shared by all groups within the community affected.

This argument has two levels. First, both the choice and the apphcation of academic standards have strikingly contingent cultural and ideological dimensions. Law faculties distribute political resources (jobs) through a process that is political in fact, if not in name. One group (white inales of the dominant culture) largely monopolizes this distribution process, and, perhaps not so surprisingly, also largely inonopolizes the benefits (jobs). This outcoine is politically illegitimate. Second, supposing that you disagree with what I have just said, and beheve that standards are and should be apolitical, that position is itself ideological. Law faculties shouldn't inake the ideological choice between colorblind meritocracy and some form of race-conscious powersharing without a substantial participation of minorities in making the decision.

\section{Cultural and Ideological Dimensions of Academic Standards.} There are different questions we ask when assessing an academic work. There is the question of truth or falsity, understood to be a question susceptible of answers that when argued out will produce a broad consensus. Then there are questions of "originality" and questions of "interest" or "value."

My experience has been that work in law (like, I assume, some work in physics) is sometimes wrong or untrue in a quite strong sense. I am convinced that when the error is pointed out just about everyone will agree that it was an error. I don't think the kinds of cultural differences that can plausibly be asserted to characterize American society have much impact on these judgments. This is sometimes true as well of questions of originality, interest and value.

Judginents of originality are obviously inore contested. And judginents of whether the problein addressed was "interesting" or "valuable" 
seem to me very strongly influenced by the politics of academic life. ${ }^{57}$ Different people in a field often have very different ideas about which true, original work is imteresting. Though the judges have a strong sense that they know whiat they mean by interest, and that they are not making "merely" subjective judginents, they also concede that the standard is difficult to apply.

More important for our purposes, they will generally concede that interest or value can be judged only by reference to a particular research tradition or scholarly paradigm, usually one among many that might have won dominance in the field. ${ }^{58}$ Yet conclusions at the level of what is valuable or interesting are very often dispositive in deciding which of two articles is better.

Once we acknowledge the possible existence of different research traditions, or collective scholarly projects, we liave to acknowledge that the white male occupants of faculty positions lave more than the power to decide which performances are better. They have also had the power to create the traditions or projects within which they will make these judgments. It seems obvious that these traditions or projects are culturally and ideologically specific products.

The projects themselves, as well as the judgments of originality, interest and value they ground (not the narrow judgments of truth and falsity) would almost certainly change if people of excluded cultures and excluded ideologies were allocated power and opportunity to create research traditions and scholarly projects of their own, or to participate im those ongoing. If this were done, there would be a gradual re-evaluation of existing legal scholarship. Some currently low-ranked work would gain esteem, and some high-ranked work would lose it. There are no meta-criteria of merit that determine which among culturally and ideologically speeific research traditions or scholarly paradigms is "better" or "truer." Judgments of merit are inevitably culturally and ideologically contingent because they are inevitably paradigm-dependent.

57. The dividing line between questions that seem "objective" and those that seem "political" or "subjective" or "cultural" or "ideological" cannot be fixed "objectively." Although, we experience merely cognitive questions (Did the article cite and discuss the leading treatise on its subject?) as very different from "value" questions (Did the article discuss the leading treatise fairly?), we also argue about which domain we are operating in. I might claim the article did discuss the treatise, although it disposed of its (silly) argument in a single sentence. You might respond that a single, dismissive sentence just does not count as discussion. I might counter that your view that there was no discussion is a disguised judgnent on the merits of the discussion. And so forth. For an analogous argument about adjudication, see D. Kennedy, Freedom and Constraint in Adjudication: $A$ Critical Phenomenology, 36 J. Legal Educ. 518 (1986).

58. See generally T. KuHN, The Structure of Scientific Revolutions (2d ed. 1970). 
The choice of standards of originality, interest and value in judging academic work has profound consequences for what a society knows about itself and its values. And for who the inembers of society are in consequence of their existence within the particular known uinverse that the knowledge-hicensers have proinoted. Who they are in turn reacts back through their powers and weaknesses onto the knowledge-licensing process that has created its own author. ${ }^{59}$

At a inuch more mundane level, the choice of standards controls the choice of personnel in the enterprise of knowledge production, which in turn affects the relative power of the cultural coinmunities that compete in civil society. Excluded communities compete in the legislative process, for exainple, on the basis of social science data asseinbled in research projects whose funding and direction is under control of the dominant community. They compete for favorable rulimgs from courts on the basis of economic theories about the relative importance of distributional equity and efficiency that are unmistakably tied to the white conservative and white moderate research agendas of law and economics scholars.

The fundamentalist has to deal with the claim that choices to allocate scholarly opportumity are grounded in power, rather than merit, and function to reproduce the very distribution of power they reflect. The power is that of white, inainly male academics, mainly of "moderate" ideology, to impose their standards. They hold, and have held for inany generations, the positions to which society has allocated authority to distribute this kind of opportumity. And they have distributed it to themselves.

As with the cultural case, there is nothing to guarantee that a larger minority legal intelligentsia would use the resources of law schools in ways that I would find pohtically constructive. More jobs might just widen the gap between scholars of color and their conmiumties, and the hiring process might select those least likely, for class and ideological reasons, to pursue the project of empowerment. If that happened, those for whom einpowerment is the goal would have to think of something else.

2. Who Gets to Decide Whether or not to Share Power? The decisionmaking process is decentralized, and largely depoliticized, in the sense of "not understood" as pohtical. The inain decisionınakers are faculty members of law schools. My (ideological) position is that the depoliticization is bad, the decentralization good. If politicization would

59. See generally 1 M. Foucault, The History of SeXuality (R. Hurley trans. 1978). 
lead to centralization within the state sector, then these positions conflict. But assume for the moment that they are not in conflict-that faculties so inclined could go a long way toward power sharing with subordinated cultural communities (and social classes) without losing their autonomy through conflict with other political institutions (sucli as state legislatures) committed to colorblind fundamentalism.

Faculties decide personnel questions by voting, usually on the basis of one-tenured-person-one-vote. In the process, individual faculty members decide between colorblind fundamentalism and the vague available alternatives. Much more important, given the pohtical weakness of advocates of alternatives, they deeide how to interpret fundamentalism in the face of its internal gaps, conflicts and ambiguities.

These choices are incomprehensible unless put in the context of conflicting ideologies about the past and present of race in the United States. The question is whether law faculties as presently constituted are tlie proper people to make these ideological decisions. Our selection processes, combined witli our historic selection practice, fail to guarantee adequately that the whole community will be represented in these decisions. That is, they are democratically inadequate. Some measure of democracy is required where decisions will affeet the very being of the community.

At this point the argument does a kind of backflip. Suppose that the fundamentalist responds to the claim of inclusion based on the political nature of knowledge production that the premise is wrong. Knowledge is true or false, not left or right. The goal is to produce as niuch of it as possible, without regard to the politics of the producers. This goal is inherently apolitical or supra-political.

The second level argument is that the question of whether these decisions are necessarily ideological is itself ideological. Even if you think knowledge production can be, is and ought to be non-political, you still liave to decide whether that view is one you should be authorized to implement institutionally without having to argue and contend with people who disagree.

Colorblind neritocratic fundamentalisn 1 is itself an ideology. The very concepts of race, culture, merit and knowledge are intensely contested both within and between groups. ${ }^{60}$ As the tone, the passion, of

60. Let me illustrate this as follows. A person from a group that has successfully used the idea of merit to wrest from a dominant group advantages previously denied on the basis of race might well have a different view of how much is lost in the use of cultural criteria from a person who was born into the dominant group. But the differences could cut many ways in generating positions. The person from the previously excluded group might conclude that merit is the only way to overcome prejudice, and that adherence will lead eventually to a society in which skin color is irrelevant. 
Kennedy's article shows on every page, it is a matter of commitment, a choice, to be a fundamentalist. He rightly presents it as a fighting faith. The question whether knowledge production is pohtical is itself political. Is the community's process for resolving the contest, its pohtical process, in short, a good one?

The current procedure is inadequate because it involves neither the normal deinocratic procedure of majority vote nor any of the inore complex procedures that often seem adequate to guarantee representation of all interests. Recognition of the political character of the decisions being made need inean neither merger into the central state apparatuses nor local "home rule" through elections. But it does inean that the licensers have to do something to brimg about aceountability for their choices between and within the competimg ideologies. That something sliould be affirmative action sufficiently extensive so that minorities have enough representation on faculties to be players in the decision about whether to adopt race-conscious decisionmaking. ${ }^{61}$

\section{Do RACE-BASEd CRITERIA OF Scholarly JudgmeNT “DEROGATE INDIVIDUALITY"?}

This Section turns to Randall Kennedy's claim that race-conscious decisionmaking "derogates froin individuality." This argument is typical of fundamentalist thinking as it might apply to a culturally and politi-

But a person from the same group might believe that as long as merit is the only basis on which to claim advances, advances will be at the expense of cultural identity and will lead to assimilation, which is cultural suicide. A person born into the dominant group might believe that the only basis on which advances are justified is merit, and that the dominant group is itself organized according to merit. Departures from race neutrality that favor the previously excluded may be necessary, but they have a heavy cost of unfairness to meritorious members of the dommant group. By contrast, some ruling class people believe that the internal meritocratic cnlture of the dominant group has large elements of sham. Also that it lias serious anti-social consequences, and that departures from its forms are likely to be beneficial even if it turns out, unhappily, that they do not lead to serious cultural pluralism.

61. One defense of the system would be that there is basic social consensus on the way faculties do their job, so that self-consciously culturally pluralist procedures are unnecessary. This would deny that colorblind fundamentalism is significantly contested, either by alternative visions or with respect to the resolution of its internal gaps, conflicts and ambiguities when we have to decide what it means in particular cases. Contra Peller, supra note 1 and articles cited in supra notes $4 \& 5$. Another (somewliat inconsistent) defense wonld be that the process of colorblind meritocratic selection, along with ideological divisions among white males, has already produced a representation of minorities and enough dissidents so that debate occurs or soon will occur within faculties. The formal adoption of power sharing is therefore not needed. Contra Chused, The Hiring and Retention of Minorities and Women on American Law School Facuities, 137 U. PA. L. Rev. 537 (1988). 
cally based affirmative action program. (As noted above, Kennedy is sympathetic to affirmative action, though on other grounds. $)^{62}$

Kennedy's article makes the familiar argument that racial categorization is dangerous per se, because it can be and and is used for racist purposes. ${ }^{63}$ I recognize that this is a danger, but $I$ think its degree has to be assessed case by case. In most situations, it is easy to distinguish between racist and anti-racist use of racial categories. Facially neutral categories can accomphish almost anything a confirmed racist would want. Whether we do better on balance by using race explicitly in institutional decisionmaking, or by finding other ways to achieve racial objectives, isn't a question to which we will ever find a decisive empirical answer. I advocate pervasive use of race-conscious decisionmaking because I don't think we can deal with the problem of subordination witliout confrontimg it directly, and I don't think we can fully achieve the value of cultural pluralism without self-consciously desigumg our institutions witl that im mind.

I don't think Kennedy's contrary position is just a matter of a different empirical-intuitive assessment of the probabilities of "misuse" or "socially destructive" application. ${ }^{64}$ Rather, it is tied to the general fundamentalist conception of prejudice and discrimination as subspecies of the evil of stereotyping. And the intense fundamentalist preoccupation witl stereotyping is, in turn, closely tied to what strikes me as the fetishizing of "individual merit." In Kennedy's article, there are a few paragraplis about the bad consequences of racial classification, ${ }^{65}$ but the theme that pervades the whole article is that: "[R]acial generalizations, whether positive or negative, derogate from the imdividuality of persons insofar as their unique cliaracteristics are submerged in the image of the group to which they are deemed to belong." 66

62. See supra text accompanying notes 16-19. See also R. Kennedy, Persuasion and Distrust, supra note 21 , at 1328-29 (affirmative action "on balance ... is useful in overcoming entrenched racial hierarchy").

63. For example, Kennedy argues that:

[T] he use of race as a proxy is specially disfavored because, even when relatively accurate as a signifier of the trait sought to be identified, racial proxies are especially prone to misuse. By the practice of subjecting governmentally-imposed racial distinctions to strict scrutiny, federal constitutional law recognizes that racial distinctions are particularly hable to be used in a socially destructive fashion.

R. Kennedy, supra note 3, at 1794 .

64. Id.

65. These include his remarks on the use of the racial distinctiveness thesis by the Nazis, among others. See id. at 1789 n.197. He also discusses the possibility that using race as an "intellectual credential" will backfire and harm minorities. See id. at 1796.

66. Id. at 1816. To derogate means "to cause to seem inferior" or "disparage" or "detract" from. WeBster's NinTH NeW Collegiate Dictionary 342 (1984). 
"Derogation from individuality" occurs whenever there is a failure to distinguish between the "will" of the individual and his or her merely "social," "accidental," "ascribed" or "inherited" characteristics. And it occurs equally whenever we fail to distinguish the act of "will" from the Inaterials, likewise merely given, on which the individual works:

[N] either one's racial status nor the experience one suffers as a result of that status is capable of translating itself into art, a point applicable as well to scholarship, the "art" of academicians. An experience is simply inert-something that happened. That something ouly becomes knowable in a public way through an act of will: interpretation. ${ }^{67}$

Kennedy's article is a brief against allowing "race-conscious decisionmaking to be assimilated into our conception of meritocracy" 68 because to do so would be unfair to "the imdividual," whether white or black, who is derried recognition of his or her "merit" in the sense of "accoinphishment" (attainment, achievement). ${ }^{9}$

67. R. Kennedy, supra note 3, at 1804 (citing R. Ellison, SHADOW AND ACT 146 (1972)).

68. Id. at 1807.

69. The following quotations show, I think, that Randall Kennedy's article is very strongly preoccupied with the "derogation of individuality," "act of will," "ascribed versus achieved," and "given materials versns willed addition" issues:

[E]ven if the scholarship at issue was narrowly concerned with the inner-experience of a single racial group, it would still be improper to presume expertise merely on the basis of a scholar's membership in a given group. One's racial (gender, religious, regional) identity is no substitute for the disciplined study essential to achieving expertise. Although one is born with certain physical characteristics to which society attaches various labels, one is not born with knowledge we expect of experts; that characteristic is attained and not merely inherited.

Id. at 1777.

My central objection to the claim of racial distinctiveness [is] . . that it stereotypes scholars. By stereotyping, I mean the process whereby the particularity of an individual's characteristics are denied by reference to the perceived characteristics of the racial group with which the individual is associated. .. But ... "any stereotype results in a partial blindness to the actual qualities of individuals, and consequently is a persistent and prolific breeding gronnd for irrational treatment of thens."

Id. at 1786-87 (quoting Lusky, The Stereotype: Hard Core of Racism, 13 Buppalo L. Rev. 450, 451 (1964)) (footnote omitted). "There are many types of classification that negate individual identity, achievement, and dignity. But racial classification has come to be viewed as paradigmatically offensive to individuality." Id. at 1794.

Rather, the point is that distance or nearness to a given subject-"outsiderness" or "insiderness"-are simply social conditions; they provide opportunities that intellectuals are free to use or squander, but they do not in themselves determine the intellectual quality of scholarly productions - that depends on what a particular scholar makes of his or her materials, regardless of his or her social position.

Id. at 1795. According to Kennedy, application of Delgado's idea of racial standing

would be bad for all scholars because status-based criteria for intellectual standing are antiintellectual in that they subordinate ideas and craft to racial status. After all, to be told that one lacks "standing" is to be told that no matter what one's inessage-no matter how true or urgent or beautiful-it will be ignored or disconnted because of who one is.

Id. at 1796.

[S]cholars should kecp racial generalizations in their place, including those that are largely aceurate. Scholars should do so by evaluating other scholars as imdividuals, without prejudgment, no matter what their hue. Scholars should ... inculcate ... a skeptical attitude 
This argument depends on our ability to separate people from their context: "As I define the term, 'merit' stands for achieved honor by some standard that is indifferent to the social identity of a given author."70 Judgments that are colored by "social identity" are "ameritocratic." Social identity gets in the way when we allow our judgment to be distorted by the skin color or ethnic experience of the person or work in question, and also when we allow personal relationships to influence us.

Kennedy's initial hist of ameritocratic motives in scholarly citation includes: "to display one's knowledge of a given hiterature, to show deference to those in a position to harm or help one's career, and to advance

toward all labels and categories that obscure appreciation of the unique features of specific persons and their work.

Id. at 1796-97 (footnotes omitted). For more, see id. at 1798 n.240. In passing, the article emphatically apphes the same individualist idea to virtue and art, as well as merit: "Participation in struggles against racial tyranny or any other sort of oppression is largely a matter of choice, an assertion of will. That is why we honor those who participate in such struggles." Id. at 1800 . Quoting Ellison: "[W]e select neither our parents, our race nor our nation .... But we do become writers out of an act of will, out of an act of choice." Id. at 1804 n.265. Back to the theme: Quoting Ellisou: "What moves a writer ... is less meaningful than what he makes of it." Id. at 1804. "A badge of inerit should not be pinned onto someone simply because she exists in a state that she had no hand in creating. Merit should be hinited to describing something that a person adds to their received condition." Id. at 1805 n.271.

The strategy of elevating racial status to an intellectual credential undermmes the conception of intelleetual inerit as a mark of achieved distinction by confusing the relationship between racial background and scholarly expertise; the former is a social condition in which one is born, while the latter is something an individual attains. Confusing accidental attributes and achieved distinctions in turu derogates the process by which all individuals, simultaneously limited and aided by the conditions they inherit, personally contribute to human cultnre.

As I use the word, "merit" is an honorific term that identifies a quality of accomplishinent that has been achieved; it does not refer to inherited characteristics such as race or gender.

Id. at $1805-06$.

"All he [Isiah Thoinas] rightly argues is . . that observers not be so overwhelmed with his God-given attributes that they fail to appreciate what he, on his own, adds to them ..." Id. at 1806 n.272.

Part I of Keunedy's article discusses the "cultural context" of the racial critiques. There is a nod to the idea that this context requires an understanding of the "relationship between knowledge and power," id. at 1749, but the overwhelming emphasis is on negative stereotyping of black intellectuals by whites. The notion of "derogation" is ceutral. See id. at 1751 ("derogatory comments") \& n.25 ("derogation of Negro capacity").

[A]lthough the overt forms of racial dommation described thus far were enormously destructive, covert color bars have been, in a certain sense, even inore insidious. After all, judgments based on expressly racist criteria inake no pretense about evaluating the inerit of the individual's work. Far more cruel are racially prejudiced judgments that are rationalized in terms of meritocratic standards. Recoguizing that American history is seeded with examples of intellectnals of color whose accomplishinents were ignored or undervalued because of race is absolutely crucial for understanding the bone-deep resentunent and distrust that finds expression in the racial critique hiterature.

Id. at 1752-53.

70. Id. at 1772 n.114. 
the careers of friends or ideological allies." ${ }^{\prime 11} \mathrm{He}$ then adds racial favoritism. ${ }^{72}$ A second list begins with "academic nepotism by using citations to promote friends." 73 Then, along with racial favoritism, he denounces "all practices that exploit the trappings of meritocracy to advance interests-friendship, the reputation of one's school, career ambitions, ideological affiliations-that have nothing to do with the intellectual characteristics of the subject being judged."74

From the point of view of the political and cultural cases for affirmative action, there are three problems with the "derogation from individuality" argument. First, it repeatedly confuses the scholarly judginent of a particular work with the judginent of a candidate for a job or promotion. It is uncontroversial that when we are assessing a particular article, we don't give it a higher quality ranking because it has a black author than we would if it had a white author. But Kennedy often seeins to interpret the "racial critiques" as though that were their position. I don't read them that way. The question is whether, in assessing candidates, we should "presume" that we will get a different and ultimately inore valuable total body of scholarly work if we allocate resources in a race-conscious way. ${ }^{75}$

71. Id. at $\mathbf{1 7 7 2}$ (emphasis added).

72. Id. at 1773 .

73. Id. at 1806.

74. Id. at 1807 (emphasis added).

75. Kennedy defines "merit" as "achieved honor by some standard that is indifferent to the social identity of a given author." $I d$. at 1772 n.114. He seems to think that from this it follows that race should not (cannot?) be an "intellectual credential."

The strategy of elevating racial status to an intellectual credential undermines the conception of intellectual merit as a mark of achieved distinction by confusing the relationship between racial background and scholarly expertise; the former is a social condition into which one is born, while the latter is something that an individual attains. Confusing aceidental attributes and achieved distinctions in turn derogates the process by which all individuals, simultaneously limited and aided by the conditions they inherit, personally contribute to human culture.

Id. at 1805-06. But the confusion here is Kennedy's. The word "credential" was introduced into his discussion of affirmative action as part of the argument that as a tnatter of probabilities we can expect to get more of some desirable capacities from minority rather than from inajority scholars:

Arguing that race should be a consideration in matching instructors to course offerings, Harvard Law School Professor Christopher Edley, Jr., maintained that "[r]ace remains a useful proxy for a whole collection of experiences, aspirations and sensitivities. ... [W] teach what we have lived ...." Similarly, Professor Derrick Bell argued that "[r]ace can create as legitinate a presumption as a judicial clerkship in filling a teaching position intended to interpret ... the impact of racial discrimination on the law and lawyering." Racial background can properly be considered a credential, he observed, because of "[t]he special and quite valuable perspective on law and life in this country that a black person can provide."

Id. at 1758 (footnotes omitted).

Richard Delgado's Imperial Scholar, supra note 4, likewise speaks in terms of probabilities in arguing that the minority community should not rely on white scholars to develop fields of law that deeply affect their interests. See R. Kennedy, supra note 3, at 1788-89. Delgado then argues that the actual outcome of white scholarship is less favorable to minority interests than minority scholarship 
Second, the cultural and ideological aspects of my achievements (accomplishments, attainments) aren't separable, for purposes of the judgment of others, from the effects of my "individuality" or of my "will." So there's nothing wrong, nothing "derogatory," im judging my work or my promise in a way that is race-conscious and sensitive to my ideological commitınents. (Of course, the judginent inay be incorrect, and it inay be prejudiced.) Third, the judginent process, whose integrity Kennedy's article wants above all to preserve, is always already corrupted by the ideological and cultural factors he wants to exclude. We avoid this only if we dehiberately impoverish and trivialize judgment by excluding the very aspects of individuals and their works that legal academics should care most about.

\section{A. Culture, Ideology and Individuality}

1. Culture. The category of culture fits neither the colorblind meritocratic view, einphasizing individual freedom to succeed or fail under universally agreed standards, nor the racialist view that biology has the power to determine people as meritorious or meritless. Its significance for fundamentalisin is that meinbership in a culture looks somewhat like a status attribute of the individual, rather than somethimg "earned" or "achieved." Culture is reproduced through child rearing and through life im a habitually closed discursive system. But people can "change cnltures" or "assimilate" to a culture other than their own. People are often "bicultural" or even "tricultural."

As with class, there seem to be no inherent limits on what a person can achieve in an adopted culture. On the other hand, assimilation is hard work, a talent in itself, and we usually think of assimilation as very different from being "born into" a culture. There are always doubts about "authenticity," or the possibility that the assimilated person is "neither fish nor fowl."

Introducing the notion of culture blurs the distinction between judging on the basis of "inere" status, assumed to have no counection with

would be, but here he is doing just what Kennedy approves. He is making substantive judgments of actual works (although he may be wrong or may not have proved his points). See id. There is no confusion between "accidental attributes and achieved distinctions."

In a footnote, Kennedy concedes that for soine jobs under some circumstances, racc would be a valid basis for favoring one candidate over another. But instead of asking whether legal academic jobs do or do not fall into this category, he instead argues that we should not use the word "merit" to describe what makes the candidate better for the job. No one is arguing about how to define the word "merit." The issue is what should count as a "credential" in a hiring situation, and Kemedy's own text here recognizes, without refuting, the type of argunnent his opponents are making. See $i d$. at 1805 n.271. 
capacities or other qualities of individuals, and judging on "achievement of the individual," assumed to be independent of status. Culture is both deeply ingrained (not changeable at will, even if changeable over the long run) and strongly differentiating; my ability to produce artifacts with ineaning is therefore tied to iny status.

This concept of culture makes the notion of "inert" experience transformed into something of value by the "individual" seein pretty crude. The individual is "made" by a whole body of experiences, shaped into a particular cultural bemg. When he or she sets out to produce an artifact out of a particular experience, what gets made is a product of all these other experiences that are collective, group, consciously and unconsciously cultural experiences. These collective things influence everything froin the way the particular "raw inaterial" is experienced to the way it is translated into whatever artifactual inedium the "individual" chooses.

Culture is an attribute of an individual that is "inherited" (though not biological), both in the sense of "coming froin the past" and in the sense of being, in any particular case, partially ineradicable through individual will. And that attribute is one that produces a heavy collective influence on all the performances and capacities of the individual. The fundamentalist cannot level against cultural claims the assertion of "irrelevance" or "irrationality" that is enough to dismiss claims based on race per se. ${ }^{76}$

76. This does not mean that only cnitures produce culture. We can still identify authors of artifacts within a cnlture and compare them. If the cnlture has only group authors, then we can distinguish between the groups. The mere existence of culture poses no a priori problems for making judgments of value between artifacts or between their creators.

It is equally wrong to think that the fact of culture (if it is a fact) makes it impossible to judge the merit of work or capacities of a person from another cniture. We can assess the ability of anyone to produce a given type of artifact of our own culture. We look at the work, not who produced it, and we just treat it as an attempted performance within our own cnlture and ask if it succeeded. Then we make inferences about the likely capacity of the individual or group author to do more work of the same quality. We can even rank cnltures according to their production of particular kinds of valued artifacts and capacities.

Yet another mistake is to believe that one can't assess the value of people or work in another culture according to its own, alien standards. A person from one cniture often has the experience of knowing what is going on im another. It is possible to pick up on the way the other culture assesses work and people, and predict accurately what the consensus view of quality in a foreign culture will be. But it is also true that what we think we know about actions or performances in another culturc is suspect in a way not true of what we think we know in our own, because we may "misread" behavior in the other cniture. Given the "inherited" quality of cnitural capacity, we never "read" in the unselfconscious way we do in our own context.

Finally, it's wrong to think there cannot be shared values between cultures. Each culture may understand the other as using the same standards for assessing particular kinds of artifacts. On the other hand, a conviction that we are applying the same standards across cultures must be held more tentatively than the same view within a cnlture. Because of "our" difference from "them," the 
At the same time, there is the experience of freedom within culture (indeed, where else could one experience it, since there is no extra-cultural space), and the experience of individual accomplishinent. A given culture may be more or less committed to the "cultural fluidity, intellectual freedom, and individual autonomy"77 Kennedy's article defends. People self-consciously make their own selection from among the positions or attitudes available within a culture (as part of the repertoire); and they choose positions and attitudes toward the very culture that constitutes their being. A person's action can change the culture that defines the possibilities of action. Recognizing culture doesn't annihilate the individual. But recognizing it does blur the bonndary between self and social context and probleinatizes the assertion that a capacity or an artifact can be divided up into one part that is the inert matter and another part that is reflective of "will," "accomplishınent" or "achievennent."

2. Ideology. Once you choose an ideology, you have "rejected one path in favor of another," and what you see and do as you travel that path will be different froin what you would have seen and done going the other way. Ideology is commitment. It is the decision to work on this line of inquiry rather than that one, to assume away these issues rather than those, in a situation where one cannot say that there was no other course available. You may be able to say that given your good faith behef $\mathrm{m}$ the rightness of your path, you obviously had no choice. But if other people believed equally in good faith that your path was wrong, and theirs right, then your choice was ideological. Once one has inade, exphicitly or imphicitly, choices of this kind, there are kinds of work one doesn't find oneself doing and kinds of problems one finds oneself ignoring.

appearance of sharing a standard may be illusory. When we discuss an evaluative or even a descriptive issue with a person from another culture on the mutual assumption that we share standards, there is always the possibility that we will find ourselves at a stalemate that seems best explained by admitting that the standards were not shared in the first place.

The point in all these cases is that we can problematize the operation of inaking judgments of value, of applying standards, without abandoning it altogether. See supra note 57. See also R. RoRty, Consequences of Pragmatism 166-67 (1982):

"Relativism" is the view that every belief on a certain topic, or perluaps about any topic, is as good as every other. No one holds this view. Except for the occasional cooperative freshman, one cannot find anybody who says that two incompatible opinions on an important topic are equally good. The philosophers who get called "relativists" are those who say that the grounds for choosing between such opinions are less algorithmic than had been thought. . . . So the real issue is not between people who think one view [is] as good as an other and people who do not. It is between those wlo think that our culture, or purpose, or intuitions cannot be supported except conversatioually, and people who still hope for other sorts of support.

77. R. Kennedy, supra note 3, at 1805. 
My view is that it just isn't possible to do legal scholarship without making choices of this kind, consciously or unconsciously. [This view is part of my ideology.] Within legal scholarship, we are fightimg out basic questions about how society is organized. More specifically, we are fighting about the hives of the ethuric minorities and majorities of the country. The descriptive and prescriptive categories we use (e.g., balancing, rights, efficiency, domination) are sharply contested among us, as are underlying conceptions of American social reality itself. ${ }^{78}$

One's ideology is more a matter of choice than one's cultural identity, but it poses similar difficulties for the fundamentalist understanding of mdividual merit. When you choose one among the possible ideological paths, you lose, as you travel along it, access to the data and the perspective you might have had along another possible path. Of course, it is not as though the view from another ideological vantage point is just unimaginable. And it is always possible to go back and start again or to set off through the underbrush. But whenever you stop and decide to write something, you do it from a particular position on the ideological map. You are enlightened but also limited, "situated" in ideological space much as you are situated in a cominunity and in a cultural identity. There is no no-position-position.

Further, ideologies are collective projects created over time. Individuals discover them, im the sense of coming upon them, but do not mvent them, any more than an imdividual can invent a culture. Once you discover an ideology, you explore it, grapple with its great figures or its everyday chiches, assimilate to it hittle by hittle or undergo conversion. You adapt it to your purposes, and perhaps try to change it, even radically, but it has a trans-imdividual contimuity. Someone else will reinterpret your remterpretation.

Finally, the "you" who pursues pre-ideological purposes is never in a purely imstrumental relation to the ideology that consciously or unconsciously provides your framework and conceptual vocabulary. The frame remakes you through and through even as "you" "use" "it." Kennedy's article treats ideological affiliation as just another bias, like friendship or the desire to advance one's career. ${ }^{79}$ But the "slant" that each person's ideological formation gives his or her work and his or her judgments of other people's work is neither an idiosyncratic individual matter, irrelevant im the same way that hair or eye or skin color is irrelevant, nor a distortion that we could purge if we tried hard enough.

78. See supra note 20.

79. See supra text accompanying notes 71-74. 
3. Individuality. Individuality, against this background, is a problematic as well as an indispensable idea. There are many possible interpretations, but two seem to me to emerge tempered rather than consumed by critical fire. Both start from the notion that culture and ideology provide a vocabulary from which "individuals" pick and choose to produce theinselves, constrained by their situation in time and space but with plenty available, even in the most apparently "disadvantaged" position, from which to make soinething that has the stamp of unpredictable humanity.

In the first interpretation, mdividuality is a pattern we read into behavior, from the most mundane to the most exalted, behavior that inay seem at first glance nothing more than a jumble of familiar eleinents culled from the stockpiles of culture, ideology and psychology. Everyone has a race, a sex, a class, a culture, ideological presuppositions, even a more or less immutable neurotic style. But no one is only these things, because each person's production of self at any given moment, in any given law review article, is a particular selection and combimation from an inexhaustible universe of possibilities. "Individuality" is an effect produced on, an experience of "readers," brought about by the juxtaposition of eleinents in a way that is neither logically coinpelled nor arbitrary, but recognizably designed to say soinething to someone.

In this way of looking at it, my imdividuality is something you have access to only through my behavior, my tone of voice or my tome on hardy perennials. I exist, even for myself, only enbedded in materials, some of iny choosing, some not, inaterials produced by others for purposes other than those I now pursue.

In the seeond interpretation of individuality, we try to get at the producer of these shows, to sneak behind the stage and confront the Wizard of $\mathrm{Oz}$. But there is an infinite regress. Who is the wizard producing the modest humbug who produced the Wizard? The condition of meeting up with another "individual," in this second view, is accepting that he or she will just appear on your wave length, in moments of intersubjective zap. There is no assurance that he or she will be there, in contact, at the next moment, or that when he or she reappears it will be as "the same person." There is no way to fix the other through understanding (through an image of what he or she is really like, or a theory of his or her personality, or whatever). Both the other and the self are unitary in the moinent but multiple over time-intelligible in the moment but contradictory taken all together. The mdividual, in this view, is what is not embedded, and therefore what is ineffable, unjudgeable, ungraspable with the apparatus of thought. 
I subscribe to both views (they do not seem to me incoinpatible), and so am happy to be called an "individualist." 80 But neither view allows the operation of meritocratic judgment of a person or a work, without regard to cultural and ideological context, that is so important in fundamentalism.

\section{B. "Individuality" Cannot Be Distinguished from Culture and Ideology}

It is not unfair to judge the individual, in deciding to hire or prounote, on the basis of the social characteristic of connection to a cultural community, because the individual cannot be separated from his or her culture in the way that Kennedy's article requires. The "individual" simply doesn't exist in that way. It is quite reasonable, and I have no cause to complam, if you expect different things of me, predict different things of me, and inake different interpretations and hence different evaluative judgments of what I say, because you know something of my cultural context.

It doesn't derogate from my individuality that you "do this to me." There just isn't work I do or a ine you can evaluate, or about whom you can make reasonable predictions, that isn't einbedded in culture. All I can do in response is to reserve the right to argue when I feel that the stereotypes you apply distort your perceptions of my meaning or my capacity.

Second, I wouldn't want iny legal scholarship to be evaluated in a colorblind way. Because we do our scholarly work in a context of culturally specific meanings, we are limited as individuals in what we can do and express, even in what we can be understood to say. But we are also einpowered to do things that are only intelligible because we do them in the particular context. Because I know that Randy Kennedy is a black American intellectual writing in 1989, I get much more out of his article than I could if I had to guess at who had written it and when and where.

In an earher article, On Cussing out White Liberals, ${ }^{81}$ Kennedy described a style of black protest and critiqued it. Racial Critiques of Legal Academia has much the same agenda. I read both articles as written in the cussing-out-black-militants genre, in which a progressive integrationist black author takes black radicals to task. I suspect that I don't pick up on all the subtleties, but because I have a notion that this genre exists,

80. The first interpretation is influenced by C. LEvi-Strauss, THE SAVAGE MIND 1-33 (1966), the second by J.-P. SARTRE, BeING AND Nothingness 3-30 (H. Barnes trans. 1956), and both by Derrida, The Law of Genre, in ON NARRATIVE (W. Mitchell ed. 1981).

81. Nation, Sept. 4, 1982, at 169. 
the article has a whole level of coherence for me that it would not otherwise have. ${ }^{82}$

An important rhetorical move in cussing is to begin with denunciations of white racism adequate to refute im advance the accusation of To1mism. Then comes the central pitch: the militants are using unsubstantiated accusations of white racist discrimination and white cultural bias as lame excuses for their own and the minority community's failure to live up to neutral standards of excellence. All the liot but in the end contentless talk about racial identity is just posturing.

Writers in this genre typically cliarge that black militant posturing diverts attention from the real problems of minority performance, and lays a spurious claim to special treatment from white institutions, a claim that white hiberals are all too willing to accept. That acceptance is condescending, because the liberals won't opeuly apply to what the militants say the same standards of sensible discourse that they apply among themselves or to their white adversaries. This reflects both white hiberal wimpiness and an underlying white racist behef that sloppy militant rhetoric is the best that can be expected from black (and Hispamic and Asian) folk.

Kennedy's article falls into the trickiest subspecies of this genre, the one that is concerned with the "acadenric study of academia." The basic move in this sub-genre is to apply the standards the militants are criticizing to the militants' own critique. Neutral standards of scholarly excellence show that the attack on neutral standards of scholarly excellence lacks scholarly excellence. This type of argument can cut to the quick because of the history of racial stereotyping of minorities as intellectually inferior, and because mainstream post-1960s political thought dismisses radical minority intellectuals as hysterical second raters or racists.

I don't think it derogatory to assess Kennedy's article as a performance in this specific genre. The article is more interesting, and also it seems to me better in soine ways and worse im others, when read as coming from a racial (cultural) and ideological position. The "individual" who wrote it is more accessible when we understand the literary materials he was working with. The danger is that we will confuse the "voice" of the genre with the actual autlior, whose individuality, as I suggested above, is ungraspable. If we confused the person with the genre in this case, it would be difficult to understand how Randy Kennedy could have written the following:

82. A striking example of the genre is Kilson, The Black Experience at Harvard, N.Y. TIMES., Sept. 2, 1973, $\S 6$ (Magazine), at 13. It is interesting to contrast the genre in which a inore or less conservative white author attacks the same black radical and white liberal characters, but in a quite different tone. See T. Wolfe, Radical Chic and MaU-Maung the Flak Catchers (1970). 
In the forties, fifties and early sixties, against the backdrop of laws that used racial distinctions to exclude Negroes from opportunities available to white citizens, it seemed that racial subjugation could be overcome by mandating the apphication of race-blind law. In retrospect, however, it appears that the concept of race-blindness was simply a proxy for the fundamental demand that racial subjugation be eradicated. This demand, which matured over time in the face of myriad sorts of opposition, focused upon the condition of racial subjugation; its target was not only procedures that overtly excluded Negroes on the basis of race, but also the self-perpetuating dynamics of subordination that had survived the demise of American apartheid. The opponents of affirmative action have stripped the historical context from the demand of race-blind law. They have fashioned this demand into a new totem and insist on deference to it no inatter what its effects upon the very group the fourteenth amendinent was crcated to protect. ${ }^{83}$

Because you know that I am a white American intellectual writing in the 1990s, there are a million things I can say in this article without saying thein, because you will infer them from this cultural context. And there are a million things you will read in that I didn't inean to be there. I see the interdependence, the inseparability of my individuality and iny context as inevitable and also as something to be embraced. Likewise my simultaneous limitation and empowerment by the fact of working in a context. My individuality is not "derogated" when I am judged and when I communicate in a context, though there is bitter with the sweet. The same is true of ideology. ${ }^{84}$

\section{Rational Meritocratic Judgment Cannot Be Culturally and Ideologically Neutral}

The flip side is that there is no evaluation aimed at getting at what I value in my own work that won't be contingent on your cultural identity. What I am trying to achieve in my work is a contribution to a cultural situation in which I am implicated, culturally specific. This is equally true of the people whose judgment I most value. If I can't be judged outside of my context, they can't judge ine outside of their context. This means that no matter low favorable the judgment, I can't take it as "objective." But it also means I can criticize critiques and reject their condemnation as "distorted." I don't have to claim or to abandon either universality or context-dependence. I can switch back and forth between the two perspectives, though without any "meta-level" assurance that I'm ever gettimg it right. All of the above applies to my ideological as well as to my cultural context.

83. R. Kennedy, Persuasion and Distrust, supra note 21, at 1335-36.

84. Cf. Frug, Argument as Character, 40 StAN. L. Rev. 869 (1988). 
There are a million misunderstandings, based on racial, ideological, national and temporal stereotypes, to which Randy Kennedy and I are subject because you read us in this context. And because you know what you know of the context, there are good readings of our texts that you may discern against our will. There is nothing we can do about this, except argue on our own behalf.

The argument may involve racism. I see racism as more than "maccurate stereotyping." It is "neurotic" in the same sense that the fetishizmg of merit is. It is msisting on the stereotype's truth because you want or need it to be true, in the face of evidence that the group or a particular member is completely different from what you expected. The racist, whether white or black, won't let you be other than what he or she wants you to be, and that is something bad. But if you accept that you have a cultural identity, the attack on it can't be dismissed as “just" irrational, in the way it could if all cultural communities were the same, or if the differences between them made no difference.

It might be true that the racist is making a correct negative judgment about soinething that really is a part of you but that there is hittle or nothing you can do about. It might be true because cultural communities are different and you have characteristics that are derived from your cultural community. The hatred you encounter is wrong or crazy, as hatred. But there might be, somewhere mixed in with it, a vatid negative judgment on your group identity. If you don't think that's so, then even after you have rejected and condemned the crazy hatred dimension, you have to defend the communal aspect of your being on the "merits."

Against this background, it seems to me legitimate and useful for Richard Delgado to attempt an exphicitly race-conscious assessinent of the white liberal constitutional law scholarship of the 1970s and 80s. "Scholars should ... evaluat[e] other scholars as individuals, without prejudgment, no matter what their hue," 85 as Kennedy's article suggests, in the sense of avoiding stereotyping like the plague. But Keunedy's article urges us (somewhat ambiguously) to "keep racial generalizations im their place, including those that are largely accurate." 86

I don't agree with this if it means that we can't try to figure out whether, for example, a distaste for the "reparations" argunient for affirmative action is a characteristic trait of a particular white hiberal noode of con law analysis. And I see nothing wrong with trying to connect such a trait to the unconscious notives of white hiberal scholars as a culturally and ideologically distinct group, or with condeinning it as a

85. R. Kennedy, supra note 3, at 1796; see also id. at 1796-97.

86. Id. at 1796. 
"defect." It is not, for me, a question of the legitimacy of a type of analy. sis, but of the plausibility of a particular interpretation. 87

In short, it is legitimate for Delgado to argue for a "linkage of White scholars' racial background to the qualities in their work that he perceives as shortcomings," 88 so long as he makes his case. ${ }^{89}$ Kennedy's article poses a false alternative:

[T] he point is that distance or nearness to a given subject- "outsiderness" or "insiderness"-are simply social conditions; they provide opportunities that intellectuals are frec to use or squander, but they do not in themselves determine the intellectual quality of scholarly productions-that depeuds on what a particular scholar inakes of his or her materials, regardless of his or her social position. ${ }^{90}$

Cultural and ideological situations are neither "sinnply social conditions" (im the sense of "imert matter") nor attributes that "determime ... imtellectual quality." They are betwixt and between. They are "formative" rather than "inert" or "determining." And this is the premise of Kennedy's own article, the first section of which is "The Cultural Con. text of Racial Critiques."

In that section, the article argues that the racial critiques "share an intellectual kinship with several well-known and influential intellectual traditions." 91 We learn that we can't "understand" the racial critiques except in the context of "the ongoing effort by intellectuals of color to control the public image of minority groups." 92 In the sections entitled, "The Racial Exclusion Claim as a Form of Pohitics," and "The Politics of Publicity," Kennedy's article assesses the arguinents of Bell, Delgado and Matsuda as the arguments of scholars of color. Their claims have

87. Along the same lines, I see nothing wrong with trying to figure out the social psychology of the preference for efficiency and "unequal bargaining power" arguments over distributional arguments in "moderate" legal scholarship, see D. Kennedy, Distributive and Paternalist Motives in Contract and Tort Law, with Special Reference to Compulsory Terms and Unequal Bargaining Power, 41 MD. L. REV. 563 (1982), or with attributing the white CLS hostility to rights rhetoric to some combination of neo-marxist ideology and middle class white cultural context. Sec Wiliams, supra note 5, at 414. As in the case referred to in the text, the question for me is not whether the type of analysis is legitimate but whether the particular instance is convincing.

88. R. Keunedy, supra note 3, at 1793 (commenting on Delgado, Imperial Scholar, supra note 4 , at 568-69).

89. Since what is involved is a cultural/ideological analysis, there is no inconsistency, indeed there is "merit" in noting that the traits are not shared by all whites and that the same traits appear in the work of some scholars of color. For a rejection of this position, see R. Keunedy, supra note 3, at 1793 .

90. Id. at 1795.

91. Id. at 1747 .

92. Id. at 1754. In the text and footnotes, Kennedy repeatedly points out the racial composition of the groups trying to control this public image, referring to the "Black Power Movement," $i d$. at 1755 , "black scholars," $i d$. at $1756 \mathrm{nn} .46 \& 48$, "black writers," $i d$. 
"an outer facet addressed principally to whites and an inner facet addressed principally to minorities."93

He then proceeds to analyze the bad motives (guilt tripping white liberals and cheerleading for minorities) ${ }^{94}$ behind their arguments in a way that seens indistinguishable from what Delgado did with the white liberal constitutional law scholars. ${ }^{95}$ His attribution of motives is a complex inference from their texts, but also from his knowledge that they are scholars of color writing im the radical intellectual tradition that he has identified, and pursuing a particular political (ideological) project.

Imagine that Kennedy's article shows up in the file of Professor Bell, Matsuda or Delgado when one of them is being considered for a lateral appointment. The article would certainly be read as an assessment of the "merit" of their scholarship, but hardly as applying a "standard that is indifferent to the social identity of a given author."96 Wouldn't it, using Kennedy's criterion, "derogate from [their] individuality . . . insofar as their unque characteristics are submerged in the image of the group to which they are deemed to belong"?97 Indeed, one might argue that the article "stereotypes" them as "militants of color" in order to cuss them out for the sins of the Black Panthers and the black sociology movement of the 1960s. ${ }^{98}$

Of course, it is not unimaginable that any of the racial critique articles could liave been written by a white. In that case, it seems likely that Kennedy's article would have levelled many of the same criticisms against the white author, but omitted some and added others. Kennedy's article asserts that "some observers do not have much confidence in the abilities, or perhaps even the capacities, of minority intellectuals. . . . [T]liey lack the sense that those with whom they disagree are their intellectual equals."99 If Bell, Matsuda or Delgado were white, Kennedy might critique the "merit" of their discussions of minority scholarship through the observation that "[s]ometimes observers display their lowered expectations . . . by more generously praising work by nimorities than they would praise similar work by whites." 100

93. Id. at 1807 (emphasis added).

94. See id. at 1808.

95. Kennedy writes, "Professor Delgado rejects both 'conscious malevolence or crass indifference.' Rather, he posits that the imperial scholars' exclusionary conduct is mainly unconscious and prompted by their desire to maintain control, to prevent scholarly criticism from becoming too threatening to the acadermic and political status quo." Id. at 1771 (footnotes omitted).

96. Id. at 1773 n.114.

97. Id. at 1816.

98. See id. at $1755 \&$ n. $44,1790$.

99. Id. at 1818-19 (footnotes omitted).

100. Id. at 1819 n.308. 
My point is not to censure Kennedy's article for "race-conscious" assessinent of inerit. It is rather that if one wants to take work like theirs seriously, as he does, it just is not possible to make the rigid separation he proposes between the authors' merely accidental or inherited aspects and their "will" or "achievement" as "individuals." Kennedy is wrong to claim that the cultural background (race) and ideological affiliations of an author "have nothing to do with the intellectual characteristics of the subjeet being judged."101

Since it is legal scholarship and law teaching that is in question, culture and ideology (inediated through intellectual paradigms and research projects) permeate the subject being judged. It is about how our culturally diverse and ideologically divided society should be organized. We can achieve colorblind neutrality and ideological neutrality ouly if we refuse to assess these aspects. Kennedy's article proposes (his own practice to the contrary notwithstanding) to judge the work without considering its subjeet and purpose. This is an evasion of politics. ${ }^{102}$

\section{Taking Colorblindness Seriously}

We could avoid all this in assessing candidates for jobs and tenure. Many law facultics adopt in practice (though not in theory) a rule that if you publish some number of articles on clearly legal topics in well regarded law reviews, you will get tenure. Period. No one will try to decide whether they think the articles are any good.

A judgment of this kind is not outside culture and ideology, because what counts as "legal," what law reviews are "well regarded," and the criteria by which those reviews judge articles subnnitted for publication, are all culturally and ideologically contingent. But it is perfectly true that when the faculty accepts the standard, they can apply it without animadversion to culture or ideology. They can grant tenure to anyone who meets the standard, even if all the articles would be culturally strange and ideologically abhorrent to them if they read them.

Another tack is to distinguish "craft" or "techinque" from substance, conceding the cultural and ideological contingency of the latter, but inanitaining neutral standards for the former. The distinction is problematic, because different cultures and ideologies and paradigms

101. Id. at 1807.

102. Kennedy remonstrates that he does not seek to evade politics. He quotes Lionel Trilling with approval:

[O]ur fate, for better or worse, is political. It is therefore not a happy fate, even if it has an heroic sound, but there is no escape from it, and the only possibility of enduring it is to force imto our definition of politics every human activity and every subtlety of human activity. There are manifest dangers in domg this, but greater dangers in not domg it.

Id. at 1787 n.191 (quoting L. Trilling, The LIBERAL IMAgination 96 (1950)). 
have different conceptions of craft. It is problematic because different paradigms may be at different levels of technical development at a given moment. But the deeper objection is that judging a work that aspires to substantive importance on this basis is arbitrary if the judges are themselves imterested in rewarding valuable substance (as well as in virtues of execution). It means we hire people who are substantively empty or evil because they are "competent." It means we refuse to hire people who have profound msights because they lack something valuable but less important.

Yet another approach is to recognize that there are "genres" of legal scholarship, and to hire or promote "the best" within each. The obvious objections here are that "outsider" judgments about what is good within a genre are likely to vary dramatically according to the ideological commitments and genre loyalties of the judger. And once one has ranked works within various genres, there is the question of allocating the "slots" among them. If you think right-wing law and economics work is the most valuable now being done im legal academia, yonr neutral "intragenre" criteria won't help you choose between a third rate econ-jock and a much higher ranked centrist "doctrinal" candidate. Some quite patently ideological or cultural criterion of appropriate pluralism will have to come im at the end, or the outcome will be random.

But what of the scholar of color who rejects this patently ideological version of standards, and himself or herself demands to be judged colorblind? ${ }^{103}$ If this demand is addressed to a law faculty that is deciding on hiring or promotion, it is misaddressed. The faculty will decide by vote, on the basis of each faculty member's understanding of the appropriate criteria. I wouldn't see myself as bound to vote agamst a candidate I would otherwise favor because the candidate wanted to be judged colorblind.

If the candidate thinks he had the benefit of what he regards as an illegitimate preference; he can refuse the job, or take it and use his power as a voting member to influence his colleagues to abandon the error of their ways. We are dealing with an ideological dispute about culturally conscious decision. I don't see a faculty member as obliged to abandon his or her position, even if the candidate views the criterion as "insulting" or as "derogating from imdividuality," unless I am persuaded on the inerits that this is the case. ${ }^{104}$

103. This last section is a response to Carter, supra note 22.

104. This view is dependent on the existence of real disagreement among minorities about affirmative action. If there were an indisputable consensus among blacks, say, that culturally conscious decisionmaking is "derogation" and "insult," and an equally indisputable willingness to abide by the consequences, it would be a tough call whether affirmative action should continue. My problem 
But now suppose I am addressed as an individual, rather than as someone voting on hiring or promotion. The deinand is simply for my judgment: Is this person of color "the best law teacher" in the school, or "the best scholar," or is this particular article the "best in the field"? Suppose further that this scholar does his or her damnedest to write as a member not of an ethnic culture but of the "cosinopohtan" culture to which Kennedy refers approvingly. ${ }^{105}$ It might be possible to answer without cultural identity playing any role at all. A white or a black scholar might so overwhelmingly dominate that it just wouldn't be plausible that anyone else could be "the best."

In this sense, law teaching and scholarship have an irreducible resemblance to a game with highly determinate rules. The resemblance is not im the rules, but in the possibility of a person being so good that any particular observer will judge without hesitation. ${ }^{106}$ This possibility also exists at the bottom end. But such cases are rare.

In the usual case, it will be possible to answer "without regard to race" only if we pose the question narrowiy enough. The article is within a particular genre. Suppose the author has either dehiberately or just naturally written it im such a way that no reader would be likely to advert to the question of the author's race in reading it. This means, as a matter of fact, that a white reader is likely to assume that the author was white, but suppose the reader is reading lots of articles and knows some of thein are by biacks. The reader can rank the articles colorblind.

If I am the reader, I will have an ideological judgment about the genre. The genre is the product of a joint scholarly endeavor in paradigm creation. It has a cultural history. The vast inajority of recogmizable genres, moreover, have a specifically white, ideologically moderate or conservative history. Their culture and ideology is built into their rules, their habitual literary and intellectuai devices. If I am asked to compare an article in such a genre with one that has a different cultural and ideological history, my comparison will be based on my own cultural and ideological situation. I can rank the black author of an antitrust article in the interest-balancing-cum-mstitutional-competence genre against other authors in the same genre witlout race having any effect on the judgment. But in the cross-genre comparison, I will understand and

would be my (ideological) conviction that the type of judgment required is both politically incorrect, impossible to do, and bad for legal scholarship. I might nonetheless feel that the value of cultural pluralism paradoxically required agreeing to the self-exclusion that would result from colorblind judgment.

105. R. Kemiedy, supra note 3, at 1802.

106. On the vexed question of the boundary between situations in which judgment seems somehow "compelled" and those in which we experience it as closer to "choice," see supra notes 57 and 76. 
rank his article as the product of a white, ideologically moderate group identity.

When I am told after the fact that the author was black, my reaction will be that the author is an excellent performer in the cultural mode of the dominant cominunity. This is a far cry from "the best, period." In other words, I do not regard the genres of the "cosmopolitan" culture as universal vessels into which each of us is free to pour his or her individual content. They are vessels but they are also molds, each with a history as part of the project of domination and subordination, as well as a history as part of the project of transcendence and enlightenment.

Now suppose the question is about teaching. I judge teachers according to the values I myself aspire to as a teacher. My view is that law teaching is inescapably an intelligentsia activity of cultural and ideological developinent in a situation of contest, domination and subordination. But I also fully recognize and embrace the craft dimension of law. I can rank teachers colorblind according to their skill in getting students to understand the meaning and relationship of an easement, a covenant and an equitable servitude. But a teacher whose course teaches only this kind of determinate content and cognitive skill is pursunig a culturally derived, ideologically charged agenda, teaching a philosophy of law by omission. The teacher who goes beyond this cognitive minimun is inoving not toward "neutrality," but toward some different, more exphicit but no less ideological philosophy of law.

Whatever the solution, from the purely cognitive to the explicitly culturally-conscious and political, the teacher's relation to the students has a symbolic dimension: the teacher is black or white, a purported "neutral, black letter man" or a touchy-feely liberal. Every teacher does something with these contingent attributes in the classroom, consciously or unconscionsly. His or her individuality does not exist in a way that can be distinguished from thein. Well, you will say, he or she could teach from behind a screen. Then the choice to use a particular voice would be a choice to situate himself or herself in the American cultural context. But he or she could write on a word processor that would flash his or her words onto the screen. Right. But the words themselves would communicate not only an individual but an individual's choices among the multiple ways of expression that cliaracterize a society divided the way ours is. And so forth.

And what would be gained by teaching from behind a screen with a word processor flashing one's words before the students? The teachers who cliose this metlod could be ranked colorblind a lot more plausibly than those who chose the "normal" inethod. But in comparing them to those who taught as culturally and ideologically situated individuals, 
openly deploying and developing those aspects of their identity, we would find ourselves judging the cultural and ideological context of the choice. Unless the fundamentalists made everyone teach their way, they could never be sure they were "the best, period," and not just "the best white" or "the best black."

In order to achieve Kennedy's ideal meritocratic academy, we have to innagine that both the bitter and the sweet of cnltural and ideological differences are eliminated or reduced to such an extent that it no longer seems important to take them into account in structuring hiring and promotion. So long as they exist, there will be an element of cnltural and ideological contingency to judginents of merit, or an element of arbitrariness im substituting "objeetive" but non-substantive criteria. I see the differences and the process of self-consciously negotiating to take the element of contingency into account as valuable in themselves. So the fundamentalist utopia seems to me impoverished. We could have colorblind meritocracy only in a society less desirable than ours would be, if we conld preserve class, cultural, community and ideological differences but consciously nnitigate their bad effects.

\section{Conclusion}

If there is a conceptual theme to this Article, it is that of "positionality," or "situatedness." The individual in his or her culture, the individual as a practitioner of an ideology, the individual in relation to his or her own neurotic structures, is always somewhere, has always just been somewhere else, and is einpowered and limited by being in that spot on the way from some other spot. Communities are like that too, though in a comphicated way. One of the things that defines a community's position-its situation, and the specific possibilities that go with it-is its history of collective accomphishınent. Another is its history of crimes against humanity. It seems unlikely that there are communities without such histories.

The crime of slavery is deep in the past of white America. But ever since slavery, in each succeeding decade after the Emancipation Proclamation, we have added new crimes until it sometimes seems that the weight of commission and onrission hes so heavily on non-white America that there just isn't anything that anyone can do about it. All anyone can hope is to be out of the way of the whirlwind, the big one and all the little ones played out in day-to-day life.

The bad history also creates opportunities that other communities don't have, or have in different ways. It would be quite something to build a multicnltural society on the basis of what has happened here, where we have neither a consensual foundation in history nor a myth of 
human benevolence to make it all seem natural. An American multicultural society will arise out of guilt, anger, mistrust, cynicism, bitter conflict, and a great deal of confusion and contradiction, if it arises at all, and would be, to my mind, the more wonderful for it.

Of course, the specific proposal put forth above, for a kind of cultural proportional representation in the exercise of ideological power through legal academia, would be a very small step in that direction. As is true of any very specific proposal that can be implemented right now by small numbers of people holding local power, it is a drop in the bucket. But the minute we imagine it as a government pohicy applied in a consistent way across the whole range of situations to which it is arguably applicable, it loses most of its appeal. First, none of us local powerholders could do much to bring it about, and, second, taking the proposal seriously as state policy might lead to all kinds of disastrous unintended side-effects.

This has been a proposal for drops in the bucket, not for the reorganization of state power. If it made a trivial contribution at vast social cost, we could abandon it as we adopted it, faculty by faculty, decision by decision. If it worked, the "kerplunk" of drops falling in near empty buckets might cause others to prick up their ears. And in any case, legal academics can and so slould exercise their power to govern themselves in accord with the ideals of democracy and intellectual integrity-ideals that white supremacy compromises all around us. 